\title{
Platinum-Zirconium Composite Thin Film Electrodes for High-Temperature Micro-chemical Sensor
}

\section{Applications}

Engin Çiftyürek ${ }^{\mathrm{a}}$, Colin D. McMillen ${ }^{\mathrm{b}}$, Katarzyna Sabolsky ${ }^{\mathrm{a}}$ and Edward M. Sabolsky ${ }^{\mathrm{a}}$

${ }^{a}$ Mechanical and Aerospace Engineering Department, West Virginia University (WVU), Morgantown, WV, 26505, USA.

${ }^{\mathrm{b}}$ Department of Chemistry, Clemson University, Clemson, SC 29634, USA.

\section{Abstract}

Stable metal interconnect thin films are critical in the development of various micro-machined devices that may operate continuously at elevated temperatures. The main objective of this work was to investigate the microstructural and electrical stability of a functionally-gradient platinum (Pt)-zirconium ( $\mathrm{Zr}$ ) composite thin film electrode designed for resistive-type chemical sensors. Thin film electrodes were fabricated using a DC magnetron sputtering process. Zirconium was used as both the conventional adhesion promoter and the Pt grain modifier within the bulk electrode microstructure. The thin film deposition was completed on highly polished alumina substrates at $200^{\circ} \mathrm{C}$. The various composite $\mathrm{Pt}$ thin films were further annealed at $1200^{\circ} \mathrm{C}$ after deposition for $1-24 \mathrm{~h}$ for rapid evaluation of the microstructure stability. This temperature was chosen since the electrodes are expected to operate beyond $1000^{\circ} \mathrm{C}$ for hightemperature MEMS applications. Scanning Electron Microscopy (SEM), Energy-dispersive X-ray Spectroscopy (EDS) and X-ray Photoelectron Spectroscopy (XPS) were conducted to characterize the alterations in chemistry, microstructure and distribution of the constituent elements through the film thickness. The electrical resistivity of the as-deposited and thermally processed Pt thin films was measured by utilizing a van der Pauw's four-point probe technique. The work identified a $\mathrm{Zr} / \mathrm{Zr}+\mathrm{Pt} / \mathrm{Pt}$ composite thin film with the $525 \mathrm{~nm}$ total film thickness that demonstrated resistivity $<5.08 \times 10^{-7} \Omega \cdot \mathrm{m}$ after being processed to $1200^{\circ} \mathrm{C}$ for $15 \mathrm{~h}$. A lift-off technique was finally used to produce a micro-electrode patterns with the optimized film structure for high-temperature applications.

Index Terms-Chemical Sensor, High-temperature, Electrode, Platinum, Zirconium, Thin film 


\section{INTRODUCTION}

Thin films of noble metals (platinum $(\mathrm{Pt})$, palladium $(\mathrm{Pd})$, ruthenium $(\mathrm{Ru})$, rhodium $(\mathrm{Rh})$ ) have widespread applications in various devices such as electrodes for chemical and electromechanical sensors and devices [1-5]. In addition, these noble metal films have found applications in high-temperature sensor applications as the elements for micro-hot plates and electrodes for structural monitoring sensors and thermocouples for harsh-environment energy applications (such as gas turbines and fuel cell systems operated at $>500^{\circ} \mathrm{C}$ ) [6-15]. Moreover, these noble metal films are also utilized to produce embedded electrodes within various electrical components, where chemical and microstructural stability is required during the thermal processing steps; examples of these include low-temperature co-fired ceramic (LTCC) microelectronic devices and multilayer piezoelectric/electrostrictive actuators and capacitors [16-24].

The application of interest for the current work is the development of resistive-type chemical microsensors that function at temperatures $>500^{\circ} \mathrm{C}$ for in-situ monitoring of gas compositions within solidoxide fuel cells and coal gasifiers. There are many publications on the fabrication and operation of resistive-type gas microsensors for applications from room temperature to $\sim 400^{\circ} \mathrm{C}$, but literature is sparse for operation beyond this temperature range. One reason for this is limitation is due to the stability and the change in the electrochemical sensing mechanism for the sensing nano- and micro-materials at these temperatures. A second limitation is the ability to pattern and stabilize microelectrodes that can operate within these harsh environments for extended periods. Resistive-type chemical microsensors based on porous oxide semiconductor films in contact with an interdigitized electrode (IDE) pattern are the most researched and developed sensor architecture. The stability of the electrical contact between the IDEs and the sensing material during sustained high-temperature operation is of prime importance in order to maintain operation with high sensitivity, low signal drift, and low noise.

Among the noble metals, Pt is well-suited for high-temperature or corrosive environment applications and would be the electrode materials of choice for this application, since it possesses a high melting point and is resistant to oxidation and chemical reaction. However, Pt has several drawbacks especially processed 
or operated at high temperatures $\left(\geq 800^{\circ} \mathrm{C}\right)$, where the metal demonstrates a high level of coarsening/agglomeration and weak adhesion when deposited on oxide or nitride surfaces, such as those typically utilized in microsensor and MEMS designs (such as $\mathrm{Al}_{2} \mathrm{O}_{3}, \mathrm{SiO}_{2}, \mathrm{Si}_{3} \mathrm{~N}_{4}$ ) [25, 26]. In other words, upon exposure to high temperature processing or operation, thin Pt films uncover the underlying oxide or nitride substrate, and the film separates into a discontinuous array of islands.

Platinum thin films are usually deposited by sputtering methods at relatively lower temperatures which is far from the thermodynamic equilibrium conditions for the film microstructure [27]. The low temperature sputtering for platinum is attractive since it enables the use of a simple lift-off process for device patterning. The lift-off process is preferred for Pt since the noble metal has a high chemical stability which makes it difficult to pattern by wet-etching, and dry-etching techniques are not conducive to low-cost production [28]. Unfortunately, the high temperature exposure of these sputtered Pt films usually results in the evolution of the microstructure due to typical dewetting, coarsening and sintering mechanisms which are all driven by the high surface energy of the microstructure (due to the fine microstructure and high defect concentration). In the end, the alteration and evolution of the Pt film microstructure results in decreased electrical functionality. Several strategies to address the high-temperature stability issues of the sputtered films have been proposed by various researchers. Budhani et al. first presented a strategy where an interface modification film was deposited between the oxide surface and Pt thin film. The microstructure was partially stabilized by introducing a 20-30 $\mathrm{nm} \mathrm{Pt}_{\mathrm{x}} \mathrm{O}_{1-\mathrm{x}}$ intermediate layer (or adhesion layer) through an oxidation process before subsequent Pt deposition [29]. The controlled oxidation of the thin Pt layer was also realized more recently by other researchers due to its promise for enhanced wetting and adhesion [3033]. Other researchers utilized alternative adhesion promoters with different thicknesses, such as 10, 20, 30, $50 \mathrm{~nm} \mathrm{Ti}$ (titanium), Ta (tantalum), and $\mathrm{Zr}$ (zirconium) films between the 360, 240, 400, $100 \mathrm{~nm}$ thick $\mathrm{Pt}$ film and the ceramic substrates. Nanometer thick films of these compositions alleviated issues with dewetting or hillock formation to a certain extent at relatively moderate temperatures $[25,30,34,35]$. Alloying or the incorporation of oxide inclusions within the Pt thin film (or bulk) were also shown to 
improve the high-temperature durability of the Pt thin films [37-39]. In addition, researchers investigated methods of incorporating alternating metal and metal oxide layered compositions into the bulk Pt thin film in order to limit sintering/coarsening processes by pinning the Pt grain boundaries [40-42]. More recently, Çiftyürek et al. utilized $35 \mathrm{~nm}$ thick $\mathrm{Hf}$ as an adhesion promoter with multiple $10 \mathrm{~nm}$ thick $\mathrm{Zr}$ as a grain pinning phase for $\mathrm{Pt}$ thin films for high temperature chemical sensor applications; the adhesion layer enhanced Pt bonding through the formation of intermetallic phases, and the layer-by-layer deposited Pt thin film showed a durable microstructure up to $48 \mathrm{~h}$ at $1200^{\circ} \mathrm{C}$ [26].

The main focus of this work was to further suppress the granular sintering/coarsening mechanism at temperatures $\geq 800^{\circ} \mathrm{C}$ for the low-temperature sputtered $\mathrm{Pt}$ thin films using a relatively simple and versatile sputtering process. The current work was initiated by re-evaluating the thermal stability of sputtered Pt films utilizing common adhesion promoters such as $\mathrm{Ti}$ and $\mathrm{Zr}$ over an alumina $\left(\mathrm{Al}_{2} \mathrm{O}_{3}\right)$ substrate. The initial work was then used to compare against an alternative DC sputtering process used to manipulate the microstructure and thickness of the $\mathrm{Zr}$ adhesion layer, where a gradient in $\mathrm{Zr}$ concentration was varied throughout the thickness of the Pt film. By manipulating the deposition parameters (such as sputtering power and primary deposition gas pressure) during the adhesion layer deposition a functionally gradient composite $\mathrm{Zr} / \mathrm{Pt}$ film was formed that demonstrated similar stability as the $\mathrm{Zr}$-Pt layer-by-layer structure demonstrated by Cunha [43] and Çiftyürek [26]. After a high-temperature stable, composite Zr/Pt film was proven, a method for fabricating the required micro-IDE pattern for sensor applications was demonstrated; this development was important since both $\mathrm{Zr}$ and $\mathrm{Pt}$ are not easily etched, especially through wet-chemical techniques. This work was realized by using a modified lift-off process for patterning the $\mathrm{Zr} / \mathrm{Pt}$ composite electrode using the optimized adhesion promoter structure and thickness. The high temperature stability of the composite thin films, as well as, the patterned microelectrodes were tested at $1200^{\circ} \mathrm{C}$ for various isothermal hold times, which is far beyond the temperature range typically used for chemical and electromechanical microsensors. 


\section{EXPERIMENTAL}

A magnetron sputtering technique operated (CVC 610 DC Magnetron Sputtering Station) at $100 \mathrm{~W}$ with a primary gas (argon) pressure of $50 \mathrm{mTorr}$ for $\mathrm{Ti}$ and $\mathrm{Zr}$ adhesion films and the primary Pt electrode film (unless otherwise indicated). The films were deposited upon polycrystalline $\mathrm{Al}_{2} \mathrm{O}_{3}$ substrates with a surface roughness $\left(\mathrm{R}_{\mathrm{a}}\right)$ of $\sim 35 \mathrm{~nm}$. All adhesion layers were deposited to the same $50 \mathrm{~nm}$ thickness, as well as, the Pt layer with $425 \mathrm{~nm}$ in thickness (unless otherwise indicated), in order to provide consistency among the deposited thin films. The film thicknesses were measured with a Tencor Alpha-Step 200 profilometer with an accuracy limit of $\pm 3 \mathrm{~nm}$. The sputtering chamber was sustained with a base pressure of $1 \times 10^{-7} \mathrm{Torr}$, and 2 inch sputtering targets were utilized.

The post-deposition annealing was completed at $1200^{\circ} \mathrm{C}$ in a conventional tube furnace (MTI GSL $1600 \mathrm{X}$ ) in order to mimic potential high temperature operation conditions. A $5 \mathrm{~K} / \mathrm{min}$ heating and cooling rates were chosen. The annealing time was varied from 1 to $24 \mathrm{~h}$ under a $\mathrm{N}_{2}$ atmosphere (with a $\mathrm{O}_{2}$ and $\mathrm{H}_{2} \mathrm{O}$ content of $2 \mathrm{ppm}$ and $3 \mathrm{ppm}$, respectively) in order to characterize the microstructural evolution due to grain growth and sintering processes for the adhesion and composite films. In order to evaluate the thin film microstructure, the film surfaces were examined using a Scanning Electron Microscopy (SEM, JEOL 7600F). Energy-dispersive X-ray Spectroscopy (EDS) and X-ray Photoelectron Spectroscopy (XPS, PHI 5000 Versaprobe) were utilized in order to determine the surface composition and chemical state of the elements, and the XPS unit was later used for depth profiling of the films. The EDS spectra were obtained using an Oxford INCA attached to JEOL 7600FE-SEM. The XPS source was operated at $15 \mathrm{kV}$ and 25 watts using $\mathrm{Al} \mathrm{K} \alpha(1486.6 \mathrm{eV})$ radiation. The films were analyzed by a combination of $117.40 \mathrm{eV}$ survey scans and $23.50 \mathrm{eV}$ detailed scans of peaks of interest. A $0.5 \mathrm{eV}$ step was used for each survey scan and a $0.05 \mathrm{eV}$ step for the detailed scan. Prior to spectral analysis, all coating surfaces were cleaned against atmospheric and post-depositional contaminations with $\mathrm{Ar}^{+}$sputter using a $2 \mathrm{kV}$ accelerating voltage for 30 seconds. The depth profile analysis was conducted with $\mathrm{Ar}^{+}$stepwise sputtering using an accelerating voltage of $2 \mathrm{kV}$ and an etching area of $1 \times 1 \mathrm{~mm}$. The X-ray induced photoelectron (XPS) data acquisition 
area was chosen to be $100 \mu \mathrm{m} \times 100 \mu \mathrm{m}$ in order to increase the accuracy in the depth profiling. All binding energies of $\mathrm{Pt}, \mathrm{Zr}$, Ti and $\mathrm{O}$ were referenced to $\mathrm{Au} 4_{\mathrm{f} 7 / 2}$ at $84.0 \mathrm{eV}$. During measurements, the analysis chamber pressure was maintained at $\sim 10^{-11}$ Torr. Finally, the room temperature electrical resistivities of the as-deposited and annealed Pt and composite films were measured using a van der Pauw's four probe technique [24]. The phase analysis and crystallinity of the as-deposited and annealed films were determined by X-ray diffraction (XRD) using a Rigaku Ultima IV powder diffractometer equipped with $\mathrm{Cu} \mathrm{K} \alpha$ radiation. The film thickness and coverage of the substrate produced geometry suitable for wide angle XRD analysis. Data was collected from $10-90$ degrees in $2 \theta$ in $0.02^{\circ}$ increments at a rate of $1 \%$ min. Phase identification was achieved through the comparison of indexed powder diffraction files maintained by the International Center for Diffraction Data (ICDD).

\section{HIGH TEMPERATURE BEHAVIOUR OF PLATINUM FILMS WITH DIFFERENT}

\section{ADHESION LAYERS}

\subsection{Platinum with Ti and Zr Adhesion Layers (Ti/Pt and Zr/Pt)}

Titanium was initially investigated as an adhesion promoter for high temperature applications $\left(\geq 800^{\circ} \mathrm{C}\right)$ of Pt electrode films due to its widespread application in the micro-electronics and sensor field [25, 34, 35, 45, 46]. As indicated in the experimental section, $425 \mathrm{~nm}$ Pt film was deposited over a $50 \mathrm{~nm}$ thick Ti and $\mathrm{Zr}$ adhesion layers. The corresponding bilayer coatings will be expressed as $\mathrm{Ti} / \mathrm{Pt}$ and $\mathrm{Zr} / \mathrm{Pt}$ throughout the paper. Fig. 1 shows the SEM micrographs of the Ti/Pt and $\mathrm{Zr} / \mathrm{Pt}$ bilayer coatings after annealing at $1200^{\circ} \mathrm{C}$ for 1 and $5 \mathrm{~h}$, respectively. The SEM micrograph shown in Fig. 1-a presents a general view of the Pt network with a highly disturbed structure and a low degree of percolation. The microstructure is separated into collection of islands due to the rapid depletion of the Ti adhesion promoter from substrate surface and the simultaneous grain coarsening of the Pt metallization. The protruding formations (see regions shown in the dashed-circles in Fig. 1-a inset) on the Pt grains were shown to be Ti rich through EDS analysis (not 
presented). Therefore, the high mobility of Ti within sputtered Pt film makes it neither a stable adhesion layer nor capable of remaining within the grain boundaries of the $\mathrm{Pt}$ film to retard the coarsening processes.

Zirconium was the second choice as an adhesion promoter. A few research groups have recently demonstrated the use of a $\mathrm{Zr}$ film as an adhesion layer or grain pinning phase for Pt thin films [36-40, 42, 47, 48]. Fig.1-b shows the SEM micrograph of the Pt film with the $\mathrm{Zr}$ adhesion layer $(\mathrm{Zr} / \mathrm{Pt})$ after $5 \mathrm{~h}$ at $1200^{\circ} \mathrm{C}$. The resulting microstructure consisted of micron-size Pt grains with a low degree of percolation across the microstructure. Detailed studies regarding the effect of different annealing conditions can be found by the current authors` previous paper regarding Zr/Pt high-temperature films [26].

It can be concluded that $\mathrm{Ti}$ and $\mathrm{Zr}$ are not suitable adhesion promoters in the bilayer thin film form, since they showed high instability and rapid adhesion depletion near the substrate interface, and the latter could not stop the coarsening of the Pt metallization. However, the $\mathrm{Zr}$ showed adequate stability as an adhesion promoter, in part due to the slow $\mathrm{Zr}$ diffusion kinetics (even at $1200^{\circ} \mathrm{C}$ ). Therefore, $\mathrm{Zr}$ would be an applicable candidate for the realization of a functionally gradient composite $\mathrm{Zr}$ and $\mathrm{Pt}$ film.

\subsection{Platinum with Double Zirconium Adhesion Layer}

As demonstrated by the degradation of the bilayer film, the use of only an adhesion layer of $\mathrm{Ti}$ or $\mathrm{Zr}$ below the sputtered Pt film resulted in the unwanted dewetting and coarsening/sintering of the film after high-temperature exposure. A strategy is required to control the migration of the adhesion layer away from the substrate interface and to limit the migration of the Pt grain boundaries, which results in unwanted grain growth. One method recently demonstrated for controlling the later mechanism is through the introduction of $\mathrm{Zr}$ metal into the $\mathrm{Pt}$ layer through a co-sputtering of $\mathrm{Zr}$ and $\mathrm{Pt}$, or through sequential depositions of each of these constituents [26, 41-43]. The dispersion of refractory particles (such as nano- or micro- $\mathrm{ZrO}_{2}$ or $\mathrm{Zr} / \mathrm{Pt}$ intermetallics) drastically reduces the low- and high- angle grain boundary mobility within the polycrystalline film. This mechanism is usually termed as Zener pinning in the literature. However, these previously demonstrated strategies are energy consuming, and/or require specialized deposition control (for 
co-deposition and processing control) to balance varying deposition rates of the two species. In order to access a similar grain-pinning strategy, this work proposes a two-layer adhesion film which consists of an initial $\mathrm{Zr}$ adhesion layer in contact with the oxide substrate and a secondary defective layer of $\mathrm{Zr}$ film deposited over the initial adhesion layer. After the deposition of the second defective $\mathrm{Zr}$ film, the Pt film is deposited over the $\mathrm{Zr}$ film, where it both infiltrates and coats over the secondary $\mathrm{Zr}$ layer. This deposition procedure results in the formation of a functionally gradient film from the original $\mathrm{Zr}$ adhesion layer to the outer Pt top layer, as shown in the cross-sectional illustration in Fig. 2-a. Fig. 2-b shows the typical crosssectional illustration of simple bilayer coating for visualization purposes.

Fig. 3 shows the high magnification SEM images of the above-mentioned two Zr layers. Fig. 3-a shows the as-deposited state of the first adhesion $\mathrm{Zr}$ thin film deposited with the same processing parameters and thickness $(50 \mathrm{~nm})$ used in the deposition of the adhesion layer for the $\mathrm{Zr} / \mathrm{Pt}$ bilayer coating. This layer shows significantly high surface coverage compared to the second defective layer, which is shown in Fig. 3-b. The second $\mathrm{Zr}$ layer is also deposited to a $50 \mathrm{~nm}$ thickness, where a $25 \mathrm{~W}$ power input and a primary gas pressure of 150 mTorr was utilized instead $100 \mathrm{~W}$ and 50 mTorr, respectively. The defective layer was generated by modification of the deposition parameters, where the parameter change resulted in a decrease in the incident energy of the deposited $\mathrm{Zr}$. This effect of primary gas pressure and power on the microstructure formation is well-documented in literature for sputtered thin films $[49,50]$. The initial layer provided a durable adhesion layer, while the latter layer provided a porous $\mathrm{Zr}$ framework, which would be later infiltrated with the deposition of $425 \mathrm{~nm}$ thick Pt top layer to form a co-continuous composite microstructure. This in-situ formed co-continuous network of $\mathrm{Zr}$ and $\mathrm{Pt}$ layer will be termed $\mathrm{Zr}+\mathrm{Pt}$ throughout the paper (see Fig. 2-a). The Zr granular network between the Pt grains would further assist in pinning of the $\mathrm{Pt}$ grain boundaries by upward diffusion beyond the $\mathrm{Zr}+\mathrm{Pt}$ co-continuous layer. The total thin film coating, with the first layer being the $\mathrm{Zr}$ adhesion layer, second layer being the $\mathrm{Zr}+\mathrm{Pt}$ cocontinuous layer and top layer being pure $\mathrm{Pt}$, will be termed as $\mathrm{Zr} / \mathrm{Zr}+\mathrm{Pt} / \mathrm{Pt}$ thorough the current work. 
Fig. 4-a and -b display SEM micrographs of the $\mathrm{Zr} / \mathrm{Zr}+\mathrm{Pt} / \mathrm{Pt}$ coating after annealing at $1200^{\circ} \mathrm{C}$ for 5 and $15 \mathrm{~h}$. The as-deposited state of Pt displays an average grain size of $\sim 15 \mathrm{~nm}$. The SEM micrographs taken after 8 and $24 \mathrm{~h}$ annealing show the successive destruction of the thin film microstructure as the isothermal hold is increased. The microstructure remained continuous during the annealing process, but larger, isolated pores with a size of $3-5 \mu \mathrm{m}$ began to emerge throughout the microstructure after $1 \mathrm{~h}$ at $1200^{\circ} \mathrm{C}$. After annealing for $5 \mathrm{~h}$ at $1200^{\circ} \mathrm{C}$, the coarsening of these isolated pores began to accelerate and merge with other larger isolated pores. Although the $\mathrm{Zr} / \mathrm{Zr}+\mathrm{Pt} / \mathrm{Pt}$ microstructure appeared to begin to evolve, the percolation was not compromised and was superior over that displayed by the Pt film with only the $\mathrm{Zr}$ adhesion layer $(\mathrm{Zr} / \mathrm{Pt})$. The rate of coarsening and coalescence of the exaggerated pores began to subside after the $5 \mathrm{~h}$ annealing, where the microstructure did not alter between the $5 \mathrm{~h}$ and $8 \mathrm{~h}$ isothermal annealing. After the $15 \mathrm{~h}$ annealing, the larger pores grew extensively and the coalescence of these pores began to compromise the percolation of the Pt phase. The percolated granular network of $\mathrm{Zr} / \mathrm{Zr}+\mathrm{Pt} / \mathrm{Pt}$ thin film was finally destroyed after $24 \mathrm{~h}$ annealing.

In contrast to the $\mathrm{Pt}$ coatings utilizing just the $\mathrm{Ti}$ and $\mathrm{Zr}$ adhesion layers (see Fig. 1), the Pt coating consisting of the double $\mathrm{Zr}$ adhesion layer demonstrated superior stability over the extended hightemperature annealing. Higher magnification SEM micrographs of the $\mathrm{Zr}$ adhesion layer (which may be observed through pores in the Pt thin film) are shown in Fig. 5-a and -b after 15 and $24 \mathrm{~h}$ annealing practices, respectively. It is worth noting that the grain growth also occurred in the $\mathrm{Zr}$ adhesion layer, where the grains grew at an average rate of $\sim 5 \mathrm{~nm} / \mathrm{h}$. The pores grew at a similar rate, but the kinetics was considerably slower than that shown for the Pt films. Annealing at $24 \mathrm{~h}$ highly disturbed the $\mathrm{Zr}$ adhesion layer as well as the Pt top layer. Fig. 5-b shows that the $\mathrm{Zr}$ adhesion layer was thoroughly disturbed beneath the Pt top layer. At a few locations, the alumina substrate became visible due to the coarsening of the adhesion layer. 


\subsection{XPS Depth Profiling of Zr/Pt and $\mathrm{Zr} / \mathrm{Zr}+\mathrm{Pt} / \mathrm{Pt}$}

The superior high-temperature stability of the $\mathrm{Zr} / \mathrm{Zr}+\mathrm{Pt} / \mathrm{Pt}$ thin film compared to the $\mathrm{Zr} / \mathrm{Pt}$ thin film demonstrated the applicability of the Zener pinning effect on the control of the Pt grain growth and dewetting characteristics. By introducing $\mathrm{Zr}$ into the $\mathrm{Pt}$ bulk composition from the start, the driving force for the diffusion of $\mathrm{Zr}$ from the adhesion layer into the bulk was decreased. This diffusion is driven by the chemical gradient across the thickness of the film. Therefore, the incorporation of the $\mathrm{Zr}$ into the Pt film limited migration of $\mathrm{Zr}$ from the adhesion layer, as is typically the case for various adhesion metals such as $\mathrm{Ti}$, Ta, and $\mathrm{Zr}$ [26]. Therefore, the preservation of the adhesion layer between the oxide and Pt film resulted in the desired effect, where the hillock and dewetting degradation mechanisms were minimized. Also, the coarsening/sintering of the $\mathrm{Pt}$ grains was controlled by the presence of the $\mathrm{Zr}$, which limited the microstructural evolution of the bulk electrode thin film. In order to characterize the distribution of the $\mathrm{Zr}$ in $\mathrm{Pt}$, XPS depth profiles of the $\mathrm{Zr} / \mathrm{Pt}$ and the $\mathrm{Zr} / \mathrm{Zr}+\mathrm{Pt} / \mathrm{Pt}$ thin films were completed by Ar ion etching through the Pt metallization towards the alumina substrate (as described in detail within the experimental section). XPS depth profile spectra were taken in the vicinity of the $\mathrm{Zr}, \mathrm{Pt}$ and $\mathrm{O}$ main photoelectron lines. The XPS depth profiles of the thin films are shown in Fig. 6, where the $0 \mathrm{~nm}$ marker represents the outside surface of the Pt metallization, and the entire thin film thicknesses were roughly 450 and $475 \mathrm{~nm} \mathrm{for} \mathrm{Zr} / \mathrm{Pt}$ and the $\mathrm{Zr} / \mathrm{Zr}+\mathrm{Pt} / \mathrm{Pt}$, respectively (thus, the alumina substrate interface is located accordingly). The figures show that the Pt concentration throughout the thin films did not change considerably; however, the $\mathrm{Zr}$ concentration increased rapidly toward the interface at different depths from the surface for the abovementioned thin films (as expected). As seen from the graphs in Fig. 6-a and -b, detection of $\mathrm{Zr}$ started at the $375 \mathrm{~nm}$ and $275 \mathrm{~nm}$ depths from the surface for $\mathrm{Zr} / \mathrm{Pt}$ and $\mathrm{Zr} / \mathrm{Zr}+\mathrm{Pt} / \mathrm{Pt}$ thin films, respectively. The early detection of the $\mathrm{Zr}$ in $\mathrm{Zr} / \mathrm{Zr}+\mathrm{Pt} / \mathrm{Pt}$ is in direct consequence of the $\mathrm{Pt}$ deposition over the defective $\mathrm{Zr}$ layer, where the Pt infiltrated the $\mathrm{Zr}$ architecture during deposition (see Fig. 3-b). In the $\mathrm{Zr} / \mathrm{Pt}$ layer, the $\mathrm{Zr}$ content gradually rose from the $375 \mathrm{~nm}$ until a depth of $\sim 412.5 \mathrm{~nm}$. In the case of double-layered thin film, the $\mathrm{Zr}$ was first detected at the $275 \mathrm{~nm}$ depth and gradually rose to $375 \mathrm{~nm}$, and this concentration was finally 
limited to a constant value between $\sim 375-425 \mathrm{~nm}$. In the $\mathrm{Zr} / \mathrm{Pt}$ case, the adhesion layer identified in Fig.3-a could not provide the same diffusional source of $\mathrm{Zr}$. The stable phases such as $\mathrm{ZrPt} / \mathrm{ZrO}_{2}$ were formed within the Pt grain boundaries during the high-temperature annealing process, which has an important effect on the high temperature behavior of the Pt thin film due to the pinning of the Pt bulk grains.

The higher stability at the elevated temperature for the $\mathrm{Zr} / \mathrm{Zr}+\mathrm{Pt} / \mathrm{Pt}$ thin film was previously attributed to the distribution and amount of the second phase precipitants among the Pt grain boundaries in the form of $\mathrm{ZrO}_{2}$ and $\mathrm{ZrPt}_{3}$. Further XPS depth profiling analysis was conducted in order to examine the concentration/distribution of the $\mathrm{Zr}$ through the thin films of $\mathrm{Zr} / \mathrm{Pt}$ and $\mathrm{Zr} / \mathrm{Zr}+\mathrm{Pt} / \mathrm{Pt}$ after $1 \mathrm{~h}$ annealing at $1200^{\circ} \mathrm{C}$. The indicated time and temperature used for annealing the samples was chosen, since samples annealed for further time lost the surface percolation, especially in the case of the $\mathrm{Zr} / \mathrm{Pt}$ and $\mathrm{Zr} / \mathrm{Zr}+\mathrm{Pt} / \mathrm{Pt}$ films, but more profoundly in the former (see Fig. 1-b and Fig. 4-b). This annealing temperature was also aligned with the operational temperature for the perspective application (where the sensor operation is perceived to be $<1200^{\circ} \mathrm{C}$ ). The thin films must be further annealed above this temperature in order to stabilize the microstructure of the electrode and sensing material for high-temperature chemical sensor applications. In addition, the refractory sensing material (oxide in many cases) must be bonded to the substrate at temperatures $>1000^{\circ} \mathrm{C}$, and thus the electrodes must be stable to this additional processing step. Therefore, the $1 \mathrm{~h}$ at $1200^{\circ} \mathrm{C}$ annealing practice could be thought of as the final step before operational usage. Fig. 6-c and $-\mathrm{d}$ show the aforementioned XPS depth profiling of the thin films of $\mathrm{Zr} / \mathrm{Pt}$ and $\mathrm{Zr} / \mathrm{Zr}+\mathrm{Pt} / \mathrm{Pt}$, respectively. XPS spectra of the 28 different locations through the coating thicknesses from the surface to the substrate interface were taken in order to better understand the overall distribution and concentration of $\mathrm{Zr}$ across this depth. Three significant locations (near surface, middle zone and substrate interface) were analyzed in detail for the chemical state and identification of the $\mathrm{Pt}$ and $\mathrm{Zr}$ in both $\mathrm{Zr} / \mathrm{Pt}$ and $\mathrm{Zr} / \mathrm{Zr}+\mathrm{Pt} / \mathrm{Pt}$ thin films. The $\mathrm{ZrO}_{2}$ phase was analyzed by using the $\mathrm{Zr} 3 \mathrm{~d}$ core photoelectron line, which includes the doublet positioned at the $185.5 \mathrm{eV}$ and $183.1 \mathrm{eV}$ for the $3 \mathrm{~d}_{3 / 2}$ and $3 \mathrm{~d}_{5 / 2}$. The intermetallic $\mathrm{ZrPt}_{3}$ phase, which is significant in this work due to its low electrical resistivity [52], was analyzed by inspecting 
detailed scans of $\mathrm{Pt} 4 \mathrm{f}$ and $\mathrm{Zr} 3 \mathrm{~d}$ photoelectron lines. The formation of $\mathrm{ZrPt}_{3}$ shows its presence at the $\mathrm{Pt} 4 \mathrm{f}$ and $\mathrm{Zr} 3 \mathrm{~d}$ spectra as shoulders on the high and low binding energy sites, respectively. The Pt main photoelectron lines are located at $72.5 \mathrm{eV}\left(4 \mathrm{f}_{7 / 2}\right)$ and $75.8 \mathrm{eV}\left(4 \mathrm{f}_{5 / 2}\right)$ for the intermetallic phases in both $\mathrm{Zr} / \mathrm{Pt}$ and $\mathrm{Zr} / \mathrm{Zr}+\mathrm{Pt} / \mathrm{Pt}$ thin film. These values for $\mathrm{Zr}$ and $\mathrm{Pt}$ are a good match with the reported literature values $[26,53,54]$.

As seen in Fig. 6-c, the $\mathrm{Zr}$ distribution through the $\mathrm{Zr} / \mathrm{Pt}$ thin film was restricted to the adhesion layer substrate interface. The $50-400 \mathrm{~nm}$ zone contains $5 \% \mathrm{Zr}$ in the form of $\mathrm{ZrO}_{2}$ and $\mathrm{ZrPt}_{3}$, while the latter is a minor contributor, since it constitutes $15 \%$ of the total $\mathrm{Zr}$ phase. On the other hand, as seen in the Fig.6-d, the $\mathrm{Zr} / \mathrm{Zr}+\mathrm{Pt} / \mathrm{Pt}$ thin film (which contains the defective adhesion layer) showed a well-distributed and high amount of $\mathrm{Zr}$ phase in the form of $\mathrm{ZrO}_{2}$ and $\mathrm{ZrPt}_{3}$ starting from surface to the adhesion layer substrate interface. The $\mathrm{ZrPt}_{3}$ consisted of nearly $30 \%$ of the total $\mathrm{Zr}$ phase within this film. The high amount and overall distribution of the $\mathrm{Zr}$ through the $\mathrm{Pt}$ electrode has significant importance not only because of microstructural stability but also electrical conductivity due to metallic conductor behavior of $\mathrm{ZrPt}_{3}$. The chemical state and concentrations analysis were conducted at three different depths; the depths were $0 \mathrm{~nm}$ (after surface cleaning with $\mathrm{Ar}^{+}, 2$ minutes at $4 \mathrm{kV}$ accelerating voltage), $225 \mathrm{~nm}$ (considered mid-depth) and $450 \mathrm{~nm}$ (considered the substrate-thin film interface). It was possible to conduct elemental concentration analysis, since the detailed spectra of the $\mathrm{Zr} 3 \mathrm{~d}$, Pt $4 \mathrm{f}$ and $\mathrm{O}$ 1s photoelectron lines were obtained at the same time. The surface of the $\mathrm{Zr} / \mathrm{Pt}$ thin film contained $8 \% \mathrm{ZrO}_{2}$, whereas the $\mathrm{Zr} / \mathrm{Zr}+\mathrm{Pt} / \mathrm{Pt}$ surface included $4.5 \% \mathrm{ZrO}_{2}$. In both of these thin films, the amount of $\mathrm{ZrPt}_{3}$ intermetallic phase counted for less than $5 \%$ of the total $\mathrm{Zr}$ content at the surface. At the mid-depth $(225 \mathrm{~nm})$, the $\mathrm{Zr} / \mathrm{Zr}+\mathrm{Pt} / \mathrm{Pt}$ thin film showed significant increase of $\mathrm{Zr}$ content $(25 \%$ in total). This increase includes the increase in the total intermetallic phase percentage to $30 \%$ of total, while the $\mathrm{ZrO}_{2}$ phase was $70 \%$ of the total. At the same depth, the total amount of $\mathrm{Zr}$ in the $\mathrm{Zr} / \mathrm{Pt}$ film was only 5\%. At the substrate-thin film interface, the $\mathrm{Zr}$ content was $\sim 10 \%$ of the total composition in the $\mathrm{Zr} / \mathrm{Pt}$ thin film, while it showed $15 \%$ for the $\mathrm{Zr} / \mathrm{Zr}+\mathrm{Pt} / \mathrm{Pt}$.

Fig. 7-a, -b and -c shows the X-ray diffraction patterns of the as-deposited, 1 and $15 \mathrm{~h}$ annealed thin films 
with double adhesion layer architecture. As can be observed from the patterns, both the as-deposited and annealed films exhibited excellent crystallinity. The pattern of the as-deposited film contains peaks attributed to $\mathrm{Pt}$ and the $\mathrm{Al}_{2} \mathrm{O}_{3}$ substrate, while the patterns of the annealed films indicate the presence of $\mathrm{ZrO}_{2}$ in addition to $\mathrm{Pt}$ and the substrate. The XRD scans are presented as the square root of intensity versus 2-theta, since the high intensity of the (111) orientation of the Pt greatly surpasses any remaining phases such as $\mathrm{Al}_{2} \mathrm{O}_{3}, \mathrm{ZrPt}_{3}$ and $\mathrm{ZrO}_{2}$. Coupled with the similarity in peak positions between Pt (PDF 00-0040802) and $\mathrm{ZrPt}_{3}$ (PDF 03-065-9551), and the low overall concentration of $\mathrm{ZrPt}_{3}$ in the film as quantified by XPS, the dominant Pt signal precludes a reliable evaluation of the $\mathrm{ZrPt}_{3}$ crystallinity. Metallic $\mathrm{Zr}$ was not observed as an independent phase in the XRD pattern of the as-deposited film, consistent with the photoelectron spectrum. However, the presence of $\mathrm{Zr}$ in the $\mathrm{ZrPt}_{3}$ intermetallic and as a dopant in $\mathrm{Pt}$ in the as-deposited film is suggested by the presence of $\mathrm{ZrO}_{2}$ in the annealed samples. The primary (111) peak of $\mathrm{ZrO}_{2}$ (PDF 00-036-0420) is observed after just one hour of annealing, and persists through longer treatments. This was confirmed by XPS as well; however, due to very close peak positional match between $\mathrm{ZrP}_{3}$ and metallic $\mathrm{Pt}$, it was not possible to analyze the crystallinity of former via X-ray diffraction data. Moreover, as it was measured via XPS, the $\mathrm{Zr}$ within the intermetallic phase $\left(\mathrm{ZrPt}_{3}\right)$ was only a small percentage, as was observed in this measurement also. Furthermore, the Pt peaks in the as-deposited film are consistently shifted to slightly lower $2 \theta$ angles compared to the annealed films. Such a shift is consistent with the Pt lattice accommodating some of the larger $\mathrm{Zr}$ atoms in the as-deposited form, which was latter followed by phase separation of the $\mathrm{ZrO}_{2}$ upon annealing (which is again consistent with the XPS analysis). The diffraction patterns are also indicative of grain coarsening in the Pt layer. The FWHM values of the Pt peaks observed in the as-deposited film are consistent with the grain size of 10-40 $\mathrm{nm}$. Upon annealing, the FWHM of the peaks decreased significantly, indicating the formation of larger grains. Increasing the annealing period from $1 \mathrm{~h}$ to $15 \mathrm{~h}$ did not appear to further decrease the FWHM values. 


\section{ELECTRICAL RESISTIVITY MEASUREMENTS}

Table 1 shows the room temperature electrical resistivities of the Pt thin films which were processed at $1200^{\circ} \mathrm{C}$ for various times (in hours). The as-deposited thin film resistivities for all coatings were higher than the reported values for bulk $\mathrm{Pt}\left(106 \times 10^{-9} \Omega \cdot \mathrm{m}\right)$ [36]. This is due to the thin film microstructure which contains significant defects, surface and interfacial roughness, oxide precipitates and grain boundaries, and also the incorporation of the lower conductivity metal (Zr). However, the as-deposited electrical resistivities are a reasonable match to the values given in literature $[55,56]$. The infinity symbol was presented within the electrical resistivity table for the samples which showed total loss of electrical conductance due to coarsening of the Pt thin film. Table 1 shows that the $\mathrm{Zr} / \mathrm{Pt}$ thin film still possessed a conductive network after $5 \mathrm{~h}$ at $1200^{\circ} \mathrm{C}$; however, the Ti/Pt lost conductivity after $5 \mathrm{~h}$ annealing at the same temperature. The $\mathrm{Zr} / \mathrm{Pt}$ thin film lost electrical conductance after $15 \mathrm{~h}$ annealing at $1200^{\circ} \mathrm{C}$. As observed in the bilayer thin films, the $\mathrm{Zr} / \mathrm{Zr}+\mathrm{Pt} / \mathrm{Pt}$ thin film also showed high resistivity compared to the value of bulk Pt in the as-deposited state. As can be shown from the SEM micrographs presented in Fig. 4, the gradual microstructural deterioration of the thin film correlated well with the gradual increase in the measured resistivity values. After the $24 \mathrm{~h}$ annealing at $1200^{\circ} \mathrm{C}$, the Pt granular network was destroyed for the $\mathrm{Zr} / \mathrm{Zr}+\mathrm{Pt} / \mathrm{Zr}$ film which resulted in the loss of the conductive network across the film.

\section{MICROELECTRODE FABRICATION AND STABILITY TESTS}

Microelectrode fabrication was completed by optical lithography over highly-polished $\mathrm{Al}_{2} \mathrm{O}_{3}$ polycrystalline substrates. The choice of photoresist was dictated by the deposition temperature. The positive resist AZ 3330-F, which is generally used for reactive-ion etching (RIE) procedures, was spincoated over the alumina substrates to a thickness of $3.5 \mu \mathrm{m}$ in order to have reasonable surface adhesion during the film deposition procedure at the elevated temperature $\left(200^{\circ} \mathrm{C}\right)$. A conventional photolithography process was carried out to define the electrode pattern within the photoresist. After the pattern was transferred, the wafers were given a post-bake at $120^{\circ} \mathrm{C}$ for 5 minutes to strengthen the photoresist. The 
general view of the as-deposited $\mathrm{Zr} / \mathrm{Zr}+\mathrm{Pt} / \mathrm{Pt}$ micro-electrode with $600 \times 1350 \mu \mathrm{m}$ and $20 \mu \mathrm{m}$ finger spacing can be seen in Fig. 8, inset shows the higher magnification of the as-deposited microelectrode. As the SEM images reveal, the pattern quality was quite satisfactory where the pattern edges are sharply defined.

To this point, the discussion on the stability of the Pt electrodes has been reserved for continuous thin films deposited over a $\sim 5 \mathrm{~cm}^{2}$ sample (without patterning). The continuous planar films represented the ideal case for the thermal stability of a patterned IDEs for micro-devices. However, the nature of the liftprocess, which includes other processing variables, may inject processing factors that could affect the microstructure or architecture of the film (and thus limit the high temperature life-expectancy). These variables would be primarily aligned with the influence of the photoresist during deposition and the potential development stage, which may produce surface/edge defects or film under-cutting. Fig. 9 shows SEM micrographs of the $\mathrm{Zr} / \mathrm{Zr}+\mathrm{Pt} / \mathrm{Pt}$ microelectrodes after annealing $15 \mathrm{~h}$ at $1200^{\circ} \mathrm{C}$. As seen in the Fig. 9$a$ and -b, the IDE pattern, including adhesion layer, was preserved with even the most vulnerable part of the pattern (corners and edges) showing high definition. As seen from Fig. 9-b, Pt microstructure coarsened to a greater extent at the edge of the electrode compared to the middle zone. In these regions, some disturbances of the $\mathrm{Pt}$ over $\mathrm{Zr}$ were observed. Although limited coarsening was seen for the $\mathrm{Pt}$ top layer (see Fig. 9-a inset), the patterned $\mathrm{Zr} / \mathrm{Zr}+\mathrm{Pt} / \mathrm{Pt}$ thin film retained a high level of percolation without isolation into discrete islands (see Fig. 9-b), which is not valid for Ti/Pt and $\mathrm{Zr} / \mathrm{Pt}$. The conductive and continuous $\mathrm{Pt}$ top layer was not lost after the high temperature annealing, and the electrode pattern retained the high level of percolation leading to excellent electrical performance in $\mathrm{Zr} / \mathrm{Zr}+\mathrm{Pt} / \mathrm{Pt}$ microelectrodes.

For comparison purposes, the $\mathrm{Zr} / \mathrm{Pt}$ thin film micro-electrode was manufactured and annealed at $1200^{\circ} \mathrm{C}$ for $15 \mathrm{~h}$. SEM micrograph of the $\mathrm{Zr} / \mathrm{Pt}$ micro-electrode after annealing is presented in Fig. 10. As seen in the image, the microstructure of the $\mathrm{Zr} / \mathrm{Pt}$ micro-electrode presents non-conductive islands of Pt. The microstructure of the $\mathrm{Zr} / \mathrm{Pt}$ microelectrode reveals a difference compared to $\mathrm{Zr} / \mathrm{Zr}+\mathrm{Pt} / \mathrm{Pt}$ microelectrode which is annealed with same conditions (see Fig. 9-b). 
For further comparison, screen-printed IDEs that are typically used for miniature sensor manufacturing in the $\mathrm{mm}$ - to $\mathrm{cm}$-size range were prepared. The Pt ink used for screen-printing was made from precipitated amorphous Pt powder purchased from Technic Engineered Powders with particle sizes around $1 \mu \mathrm{m}$. The screen-printed electrodes had a total length of $10 \mathrm{~mm}$ with finger width and finger spacing of $400 \mu \mathrm{m}$ and $10 \mu \mathrm{m}$ in film thickness. The thick film (screen-printed) electrode with the large grain size Pt should resist the effect of coarsening/sintering at these high temperatures compared to thin film micro-electrodes. After annealing at $1200^{\circ} \mathrm{C}$ for $15 \mathrm{~h}$, the IDEs formed with the screen-printed Pt powder showed a highly disrupted microstructure. The microstructure displayed separate Pt islands in the size range of $5 \mu \mathrm{m}$ with various size pores separating these islands. The microstructure is in far contrast to that shown for the $\mathrm{Zr} / \mathrm{Zr}+\mathrm{Pt} / \mathrm{Pt}$ thin film micro-electrode structure processed at the same conditions (see Fig. 9). The $\mathrm{Zr} / \mathrm{Zr}+\mathrm{Pt} / \mathrm{Pt}$ microelectrode architecture was successfully implemented in the resistive-type chemical microsensors for high temperature and reducing environments for the first time, the conditions have never been reported in literature for resistive-type sensors [57-59].

\section{CONCLUSION}

The paper investigated a DC sputtering process for fabricating a functionally-gradient $\mathrm{Pt}$ and $\mathrm{Zr}$ composite microstructure with three deposition steps. The resultant microstructure of the composite electrode thin film was shown to be stable up to $1200^{\circ} \mathrm{C}$. The microstructural stability of the Pt thin films with the incorporation of $\mathrm{Zr}$ within the bulk was characterized by SEM, EDS and XPS after high temperature annealing. The microstructural stability of the $\mathrm{Zr} / \mathrm{Zr}+\mathrm{Pt} / \mathrm{Pt}$ film architecture was attributed to the distribution of $\mathrm{Zr}$ throughout the bulk of the film during the three-step deposition process. The presence of the $\mathrm{Zr}$ deep within the Pt bulk microstructure resulted in the pinning of the Pt grain boundaries by the resultant $\mathrm{ZrO}_{2}$ and $\mathrm{ZrPt}_{3}$ phases, which in the end, impeded the sintering and coarsening of the Pt grains. Also, the presence of the $\mathrm{Zr}$ within the bulk Pt film decreased the migration of the $\mathrm{Zr}$ away from the adhesion layer at the oxide substrate surface. This migration of the metal/metal oxide adhesion layer film 
from this interface was previously shown to be a key characteristic leading to hillock formation (dewetting) of the precious metal electrode films (on oxide substrates) after high temperature processing (especially for $\mathrm{Ti}$ and Ta adhesion films). The four-point probe electrical resistivity measurements were also conducted in order to correlate the effect of microstructural alterations to the electrical conductance of the thin films after various annealing schedules. The electrical resistivity measurements agreed on the retention of the percolated conductive network for the $\mathrm{Zr} / \mathrm{Zr}+\mathrm{Pt} / \mathrm{Pt}$ type thin film.

The DC sputtering technique used to deposit the composite film in this work was proven to be an efficient method that did not require the use of various Pt solid solution targets or expensive dual-sputtering capabilities. In addition, the methods used were compatible to typical lift-off techniques for producing micro-patterned electrodes consisting of the high temperature stable $\mathrm{Pt}$ films $(\mathrm{Zr} / \mathrm{Zr}+\mathrm{Pt} / \mathrm{Pt})$. The microelectrodes formed with this technique performed similar to its thin film counterpart characterized throughout the work.

\section{Acknowledgment}

This research was funded by US Department of Energy University Coal Research (UCR) program under contract DE-FE0003872. We acknowledge the use of the WVU Shared Research Facilities. The authors also would like the acknowledge Dr. Kolin Brown, Dr. Wei Ding, Mr. Harley Hart for their assistance.

\section{REFERENCES}

1. Ekkels P, Rottenberg X, Puers R and Tilmans J 2009 J. Micromech. Microeng. 19065010

2. Tiggelaar R M, Berenschot J W, de Boer J H, Sanders R G P, Gardeniers J G E, Osterbroek R E, van den Berg A, and Elwenspoek M C, 2005 Lab. Chip. 5 326-336

3. Tortissier G, Blanc L, Tetelin A, Lachaud J L, Benoit M, Conédéra V, Dejous C, Rebière D, 2011 Sensors Actuators B, 156 510-516

4. Patel S V, Di Battista M, Gland J L, Schwank J W, 1996 Sensors Actuators B 37 27-35

5. Nakagomi S, Sai T, Kokubun Y, 2013 Sensors Actuators B 187 413-419

6. Zhang L, Li L, Zhao F, Chen F, Xia C, 2011 Solid State Ionics 192 557-560

7. Tougas I M, Amani M, Gregory O J, 2013 Sensors, 13 15324-15347

8. Takeuchi Y, Shibata K, 2003 U.S. Patent, 6657364 
9. Hamidon M N, Skarda V, White N M, Krispel F, Krempl P, Binhack M, Buff W, 2005 Sensors Actuators A 123-124 403-407

10. Lee C Y, Lee S J, Hsieh C L, 2007 Proc. NEMS-IEEE Inter. Conf. 434-437

11. Wright S A, Gianchandani Y B, 2007 Proc. MEMS IEEE 20th Inter. Conf. 115-118

12. Martin L C, Holanda R, 1994 NASA Technical Memorandum NASA-IM-106714

13. Wrbanek J D, Laster K L H, 2005 NASA Technical Memorandum NASA-TM-213433

14. Bonfert D, Gieser H, Bock K, Svasta P, Ionescu C, 2010 Proc. SIITME-IEEE 83-88

15. Lei J F, Martin L C, Will H A, 1997 NASA Technical Memorandum 107418

16. Huff A. M, Ozgur M, 2006 U.S. Patent, 7045440

17. Vessel J K, 2004 Handbook of Advanced Materials:Enabling New Designs

18. Murray J, Song K, Huebner W, O'Keefe M, 2012 Mater. Lett. 74 12-15

19. Jantunen H, Kangasvieri T, Vähäkangas J, Leppävuori S, 2003 J. Eur. Cera. Soc., 23-14 2541-2548

20. Golonka L, Bembnowicz P, Jurków D, Malecha K, Roguszczak H, Tadaszak R, 2011 Optica Applicata $41383-388$

21. Annas S, 2003 ECTC Conf. Proc.1691-1693

22. Peterson K A, Patel K D, Ho C K, Rohde S B, Nordquist C D, Walker C A, Wroblewski B D, Okandan M, 2005 Int. J. Appl. Ceram. Technol. 2 345-363

23. Lauffer J M, Schumacher R A, 1991 U.S. Patent 5027253

24. Rubio M R G, Vallejos P E, Laguna L S, Aviles J J S, 2001 Sensors Actuators A 89 222-241

25. Firebaugh S L, Jensen K F Schmidt M A, 1998 J. Microelectromech. Syst. 7 128-135

26. Çiftyürek E, Sabolsky K, Sabolsky E M, 2013 Sensors Actuators B 18 702-714

27. Petrov I, Barna P B, Hultman L, Greene J E, 2003 J. Vac. Sci. Technol. A, 21 S117

28. Tong H D, Zwijze R A F, Berenschot J W, Wiegerink R J, Krijnen G J M, Elwenspoek M C, 2000 Proc. SeSens workshop on Semiconductor Sensor and Actuator Technology

29. Budhani R C, Prakash S, Doerr H J, Bunshah R F, 1986 J. Vac. Sci. Technol. A 4 3023-3024

30. Tiggelaar R M, Sanders R G P, Groenland A W, J G E Gardeniers, 2009 Sensors Actuators A 152 39-47

31. Lee D S, Chun D, Park D Y, Ha J W, Yoon E J, Kim M H, Woo H J, 1998 U.S. Patent 5736422

32. Woo H J, Park D Y, Lee D S, Chun D I, Yoon E J, 2000 U.S. Patent 6054331

33. Wrbanek J D, Laster K L H, 2005 NASA Technical Memorandum NASA/TM-213433

34. Puigcorbe J, Vogel D, Michel B, Vila A, Gracia I, Cane C, Morante J R, 2003 J. Micromech. Microeng. 13 119-124

35. Esch H, Huyberechts G, Mertens R, Maes G, Manca J, De Ceuninck W, De Schepper L, 2000 Sensors Actuators B 65 190-192 
36. Howard J K, Srikrishnan K V, 1981 U.S. Patent, 4423087

37. Selman G L, Day J G, Bourne A A, 1974 Platinum Met. Rev. 18 46-57

38. McGrath R B, Badcock G C, 1987 Platinum Met. Rev 31 8-11

39. Popoola A I, Chown L H, Cornish L A, 2014 Turkish J. Phys., 38 10-16

40. da Cunha M P, Moonlight T, Lad R, Frankel D, Bernhardt G, 2008 Sensors Conf., IEEE 752-755

41. Courbat J, Briand D, de Rooij N F, 2008 Sensors Actuators A, 142 284-291

42. Frankel D J, Bernhardt G P, Sturtevant B T, Moonlight T, da Cunha M P, Lad R J, 2008 Proc. IEEE Sensors Conf. 82-85

43. da Cunha M P, Moonlight T, Lad R, Bernhardt G, Frankel D J, 2007 Proc. Ultras. Symp. IEEE 21072110

44. van der Pauw L J, 1958 Philip Res. Rep., Eindhoven, Netherlands.

45. Sreenivas K, Reaney I, Maeder T, Setter N, Jagadish C, Elliman R G, 1993 J. App. Phys. 75 232-239

46. Tisone T C, Drobec J, 1972 J. Vac. Sci. Technol. A 9 271-275

47. Maeder T, Sagalowicz L, Muralt P, 1998 JAPAN J. Appli. Physi. 37 2007-2012

48. Mardare C C, Joanni E, Mardare A,I, Fernandes J R A, de Sá C P M, Tavares P B, 2005 Appl. Surf. Sci. $243113-124$

49. Ryll T, Galinski H, Schlagenhauf L, Jennifer P E, Rupp L M, Hutter A B, Gauckler L J, 2011 Adv. Func. Mater. 21 565-572

50. Ohring M, Material Science of Thin Films $2^{\text {nd }}$ edition ISBN 978-0-12-524975-1

51. Moulder J F, Stickle W F, Sobol P E, Bomben K D, 1992-1995 Handbook of X-Ray Photoelectron Spectroscopy 108-109 168-171 180-181

52. Pecora L M, Ficalora $P$ J, 1977 J. Electron. Mater. 531-540

53. Wertheim G K, Buchanan D N E, 1989 Phys. Rev. B 40 5319-5324

54. Fisher R F, Alvey M D, Georgea P M, 1992 J. Vac. Sci. Technol. A 10 2253-2260

55. Schmid U and Seidel H, 2008 Thin Solid Films 516 898-906

56. Lee J M, Hong S K, Hwang C S, Kim H J, 1998 J. Korean Phys. Soc. 33148151

57. Wildfire C, Çiftyürek E, Sabolsky K, Sabolsky E M, J. Electrochem. Soc. (JES), 161 (2) B3094-B3102 (2014), JES Focus Issue on Microfluidics, MEMS/NEMS, Sensors and Devices.

58. Wildfire C, Çiftyürek E, Sabolsky K, Sabolsky E M, J. Mater. Sci., July 2014, Volume 49, Issue 14, pp 4735-4750.

59. Wildfire C, Çiftyürek E, Sabolsky K, Sabolsky E M, ECS Transactions, 61 (2) 375-385 (2014). 


\section{List of Table:}

Table 1. Electrical Resistivity of Pt Coatings $\left(10^{-9} \Omega . m\right)$ After Annealing at $1200^{\circ} \mathrm{C}$ for $1,5,15,24,48 \mathrm{~h}$.

\section{List of Figures:}

Fig. 1: SEM images from surface of (a) Ti/Pt after annealing at $1200^{\circ} \mathrm{C}$ for $1 \mathrm{~h}$, inset shows the migrated $\mathrm{Ti}$ accumulation on the Pt grains (b) $\mathrm{Zr} / \mathrm{Pt}$ after annealing at $1200^{\circ} \mathrm{C}$ for $5 \mathrm{~h}$.

Fig. 2: Cross-sectional schematic illustrations of (a) functionally gradient composite $\mathrm{Zr}$ and $\mathrm{Pt}$ films ( $\mathrm{Zr} / \mathrm{Zr}+\mathrm{Pt} / \mathrm{Pt})$, during Pt film deposition, in-situ formation of co-continuous composite of $\mathrm{Zr}$ and $\mathrm{Pt}$, called $\mathrm{Zr}+\mathrm{Pt}$ shown in shaded region. (b) Bilayer coatings of $\mathrm{Zr} / \mathrm{Pt}$ or $\mathrm{Ti} / \mathrm{Pt}$ (Illustrations are not scaled to real dimensions of the abovementioned layers)

Fig. 3: SEM micrographs of as-deposited state of (a) First layer of $\mathrm{Zr}$ adhesion layer common in $\mathrm{Zr} / \mathrm{Pt}$ and $\mathrm{Zr} / \mathrm{Zr}+\mathrm{Pt} / \mathrm{Pt}$ (b) Defective layer of $\mathrm{Zr}$ utilized in $\mathrm{Zr} / \mathrm{Zr}+\mathrm{Pt} / \mathrm{Pt}$ coating as a second layer of double adhesion layer.

Fig. 4: $\mathrm{Zr} / \mathrm{Zr}+\mathrm{Pt} / \mathrm{Pt}$ thin film after annealing at $1200^{\circ} \mathrm{C}$ for (a) $5 \mathrm{~h}$ (b) $15 \mathrm{~h}$.

Fig. 5: High magnification SEM micrographs of adhesion layer in $\mathrm{Zr} / \mathrm{Zr}+\mathrm{Pt} / \mathrm{Pt}$ after annealing at $1200^{\circ} \mathrm{C}$ for (a) $15 \mathrm{~h} \mathrm{(b)} 24 \mathrm{~h}$.

Fig. 6. XPS depth profiling of the as-deposited (a) $\mathrm{Zr} / \mathrm{Pt}$ (b) $\mathrm{Zr} / \mathrm{Zr}+\mathrm{Pt} / \mathrm{Pt}$ and annealed for $1 \mathrm{~h}$ at $1200^{\circ} \mathrm{C}$ (c) $\mathrm{Zr} / \mathrm{Pt}(\mathbf{d}) \mathrm{Zr} / \mathrm{Zr}+\mathrm{Pt} / \mathrm{Pt}$ thin films.

Fig. 7: X-ray diffraction scan of as-deposited (a) 1 (b) and 15 (c) h 1200C annealed samples.

Fig. 8: SEM micrographs of as-deposited $\mathrm{Zr} / \mathrm{Zr}+\mathrm{Pt} / \mathrm{Pt}$ microelectrodes, showing high-magnification images (inset shows edges clearly defined).

Fig. 9: $\mathrm{SEM}$ micrographs of the $\mathrm{Zr} / \mathrm{Zr}+\mathrm{Pt} / \mathrm{Pt}$ microelectrodes after annealing at $1200^{\circ} \mathrm{C}$ for $15 \mathrm{~h}$ (a) highmagnification close-ups for showing edges clearly (b) high-magnification taken form imminent edge of the microelectrode shows Pt top layer and adhesion layer over substrate.

Fig. 10: SEM micrograph of the partial view of $\mathrm{Zr} / \mathrm{Pt}$ microelectrode after annealing at $1200^{\circ} \mathrm{C}$ for $15 \mathrm{~h}$. 
Table 1. Electrical Resistivity of Pt Coatings $\left(10^{-9} \Omega . \mathrm{m}\right)$ After Annealing at $1200^{\circ} \mathrm{C}$ for $1,5,15,24$ and 48 h. The infinity symbol represents discontinuous (dewetted) thin films.

\begin{tabular}{|c|c|c|c|c|c|l|}
\hline $\begin{array}{c}\text { Coating } \\
\text { Type }\end{array}$ & As-deposited & $1 \mathrm{~h}$ & $5 \mathrm{~h}$ & $15 \mathrm{~h}$ & $\mathbf{2 4} \mathrm{h}$ & $\mathbf{4 8} \mathrm{h}$ \\
\hline $\mathrm{Ti} / \mathrm{Pt}$ & 220 & 581 & $\infty$ & $\infty$ & $\infty$ & $\infty$ \\
\hline $\mathrm{Zr} / \mathrm{Pt}$ & 199 & 232 & 694 & $\infty$ & $\infty$ & $\infty$ \\
\hline $\mathrm{Zr} / \mathrm{Zr}+\mathrm{Pt} / \mathrm{Pt}$ & 219 & 257 & 289 & 508 & $\infty$ & $\infty$ \\
\hline
\end{tabular}


Click here to download high resolution image

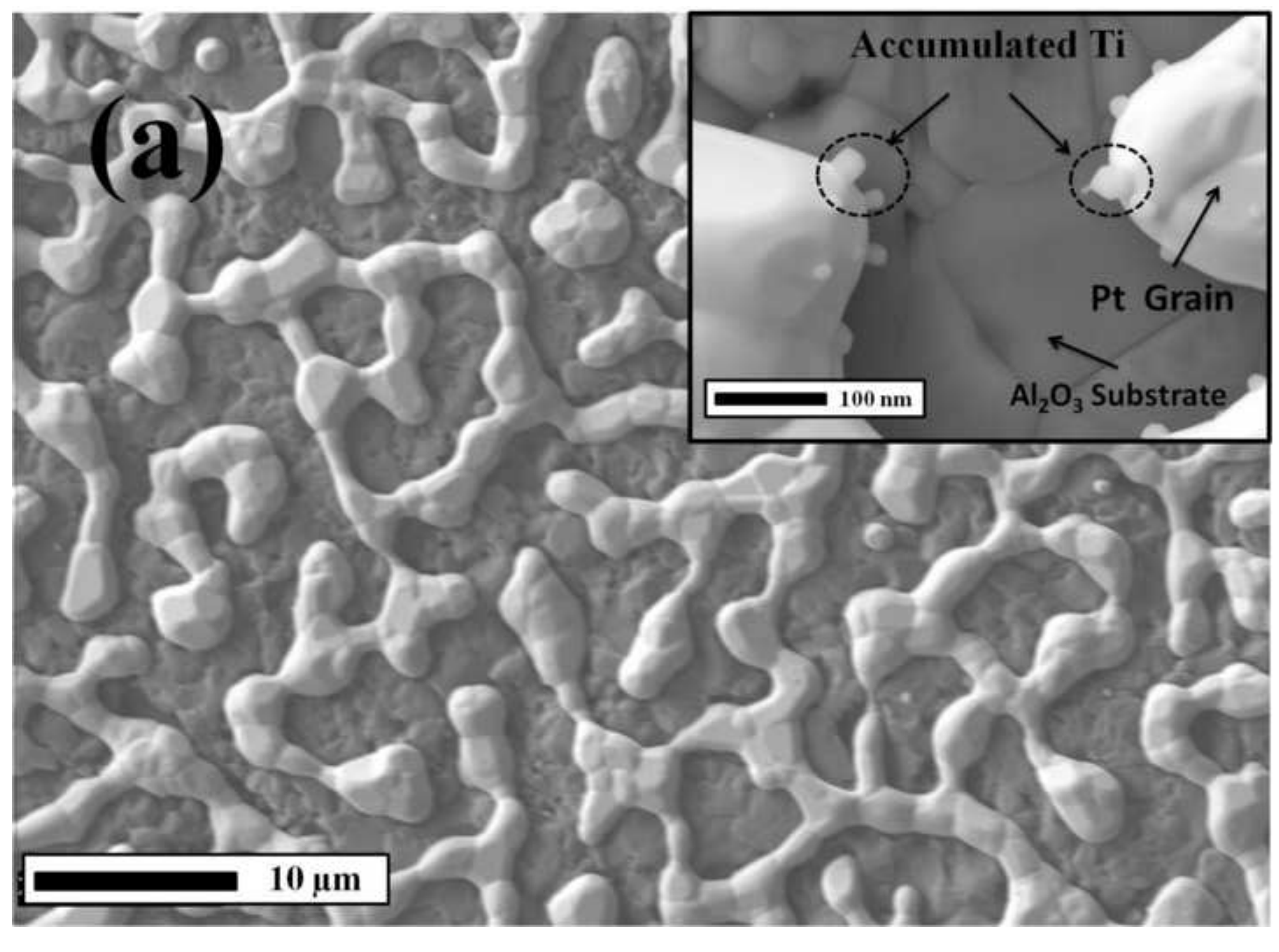

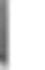
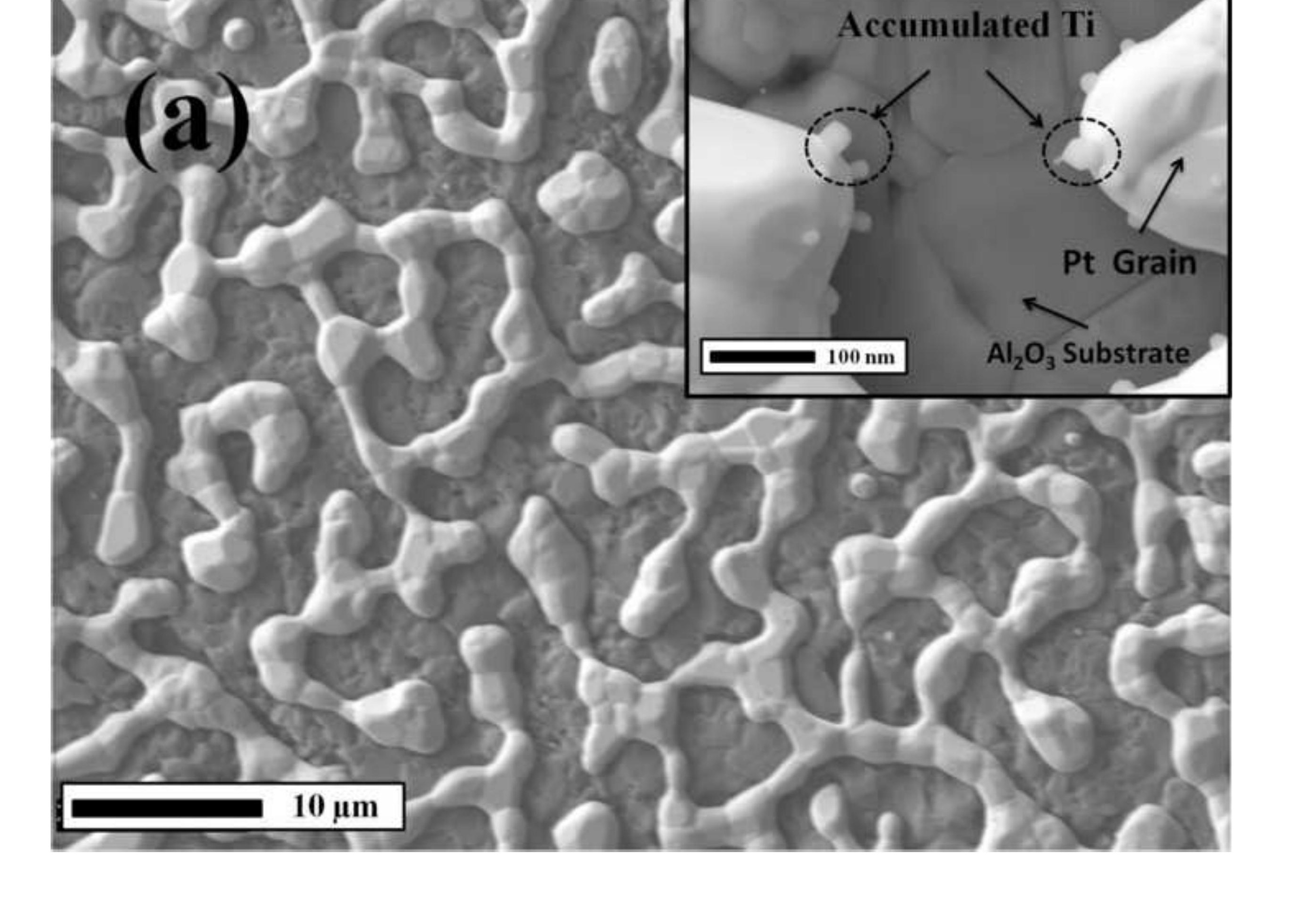


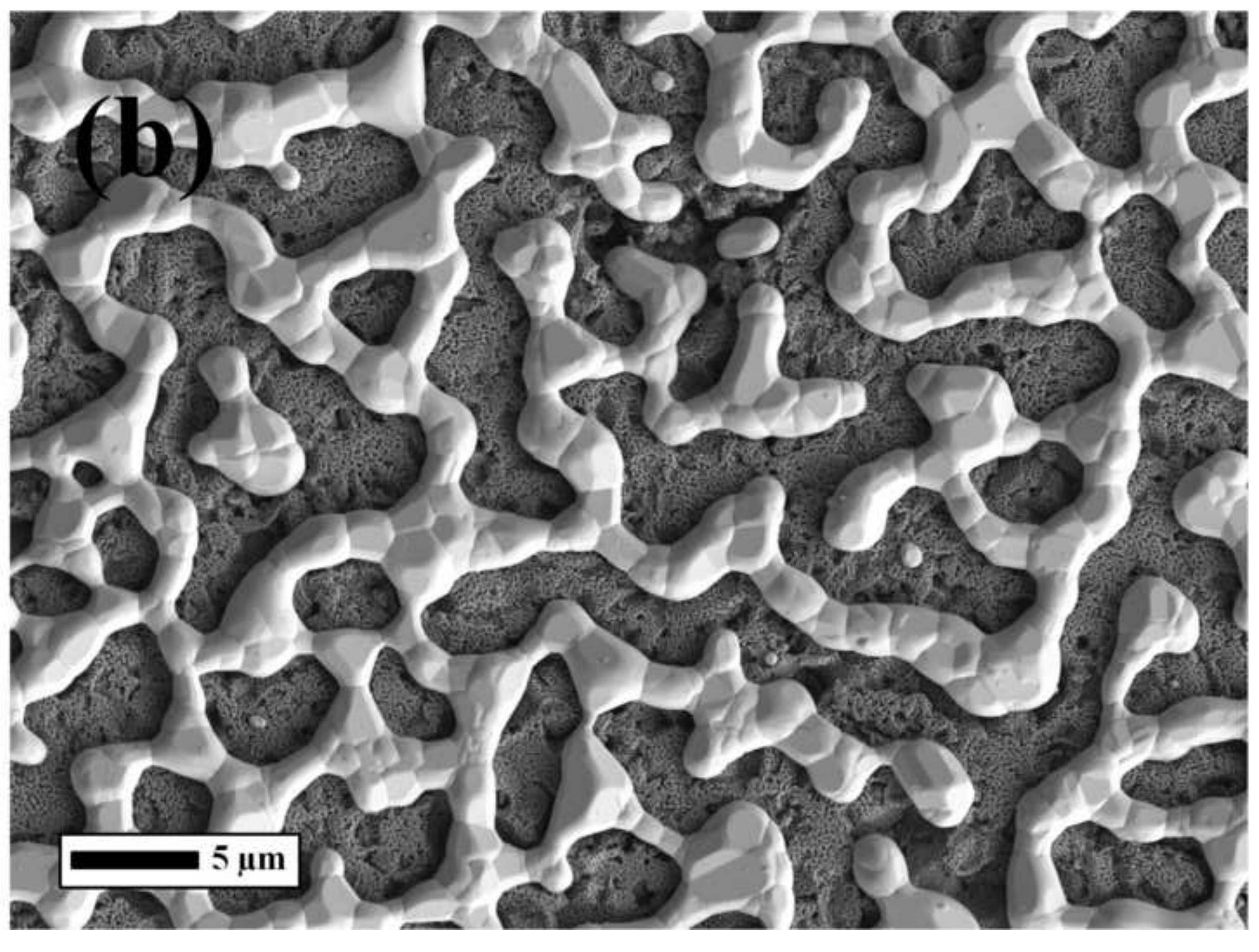

\section{Click here to download high resolution image
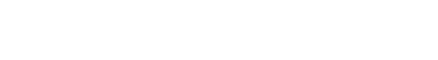

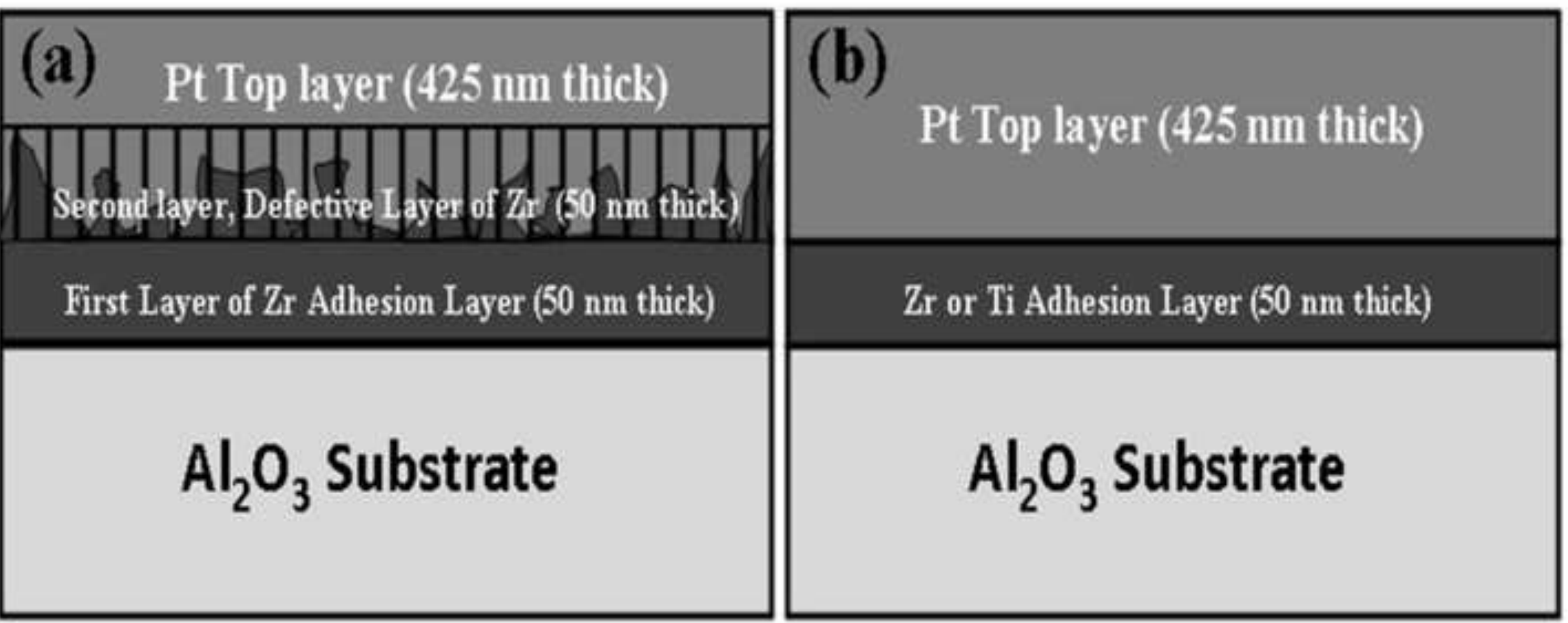

\title{
$\mathrm{Al}_{2} \mathrm{O}_{3}$ Substrate
}

\author{
$\mathrm{Al}_{2} \mathrm{O}_{3}$ Substrate
}


Click here to download high resolution image

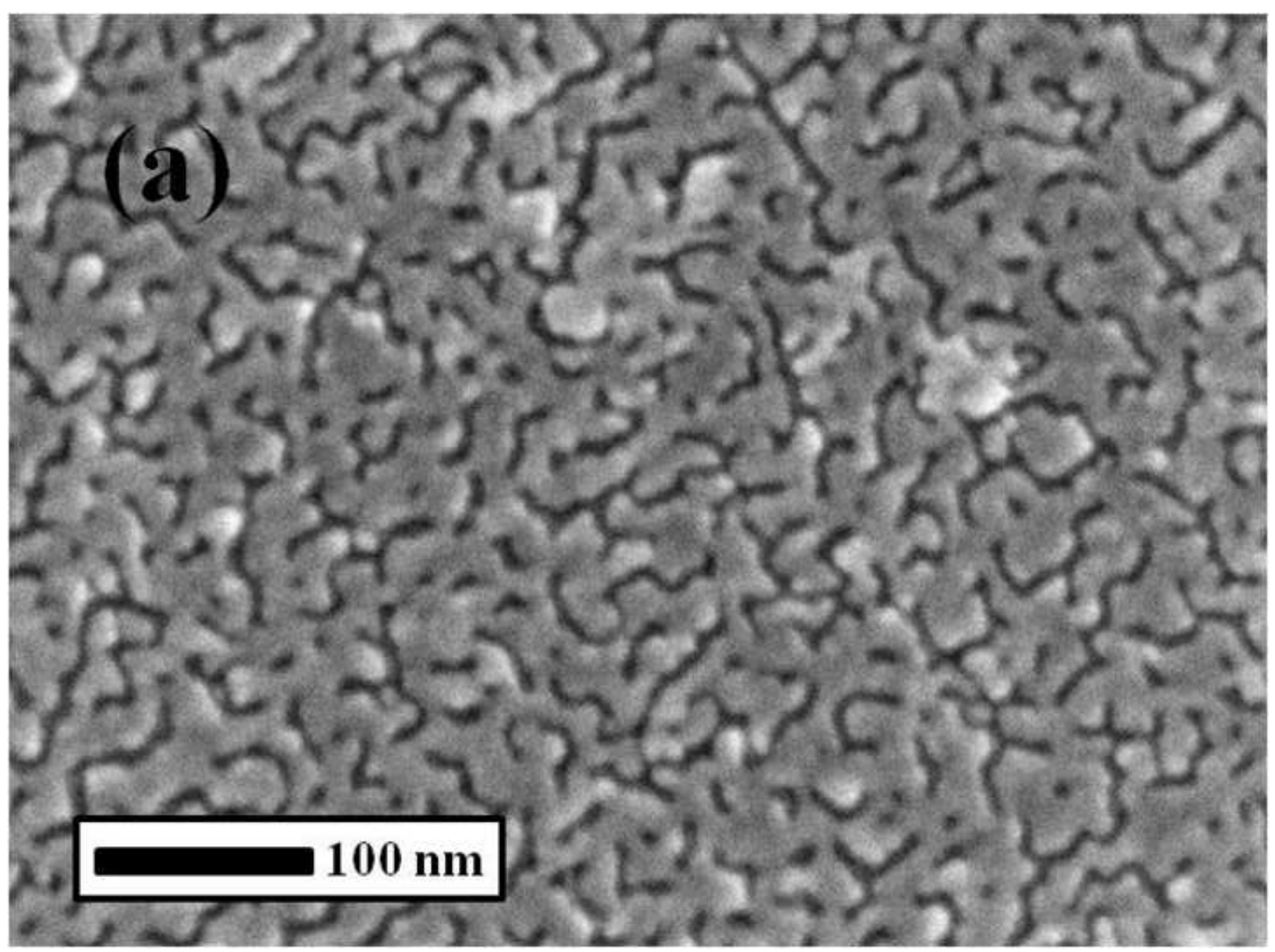


Figure 3_b
Click here to download high resolution image
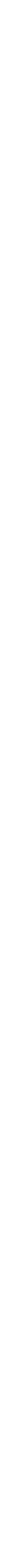
Figure_4_a
Click here to download high resolution image
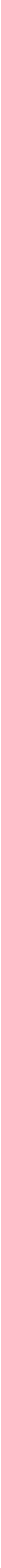

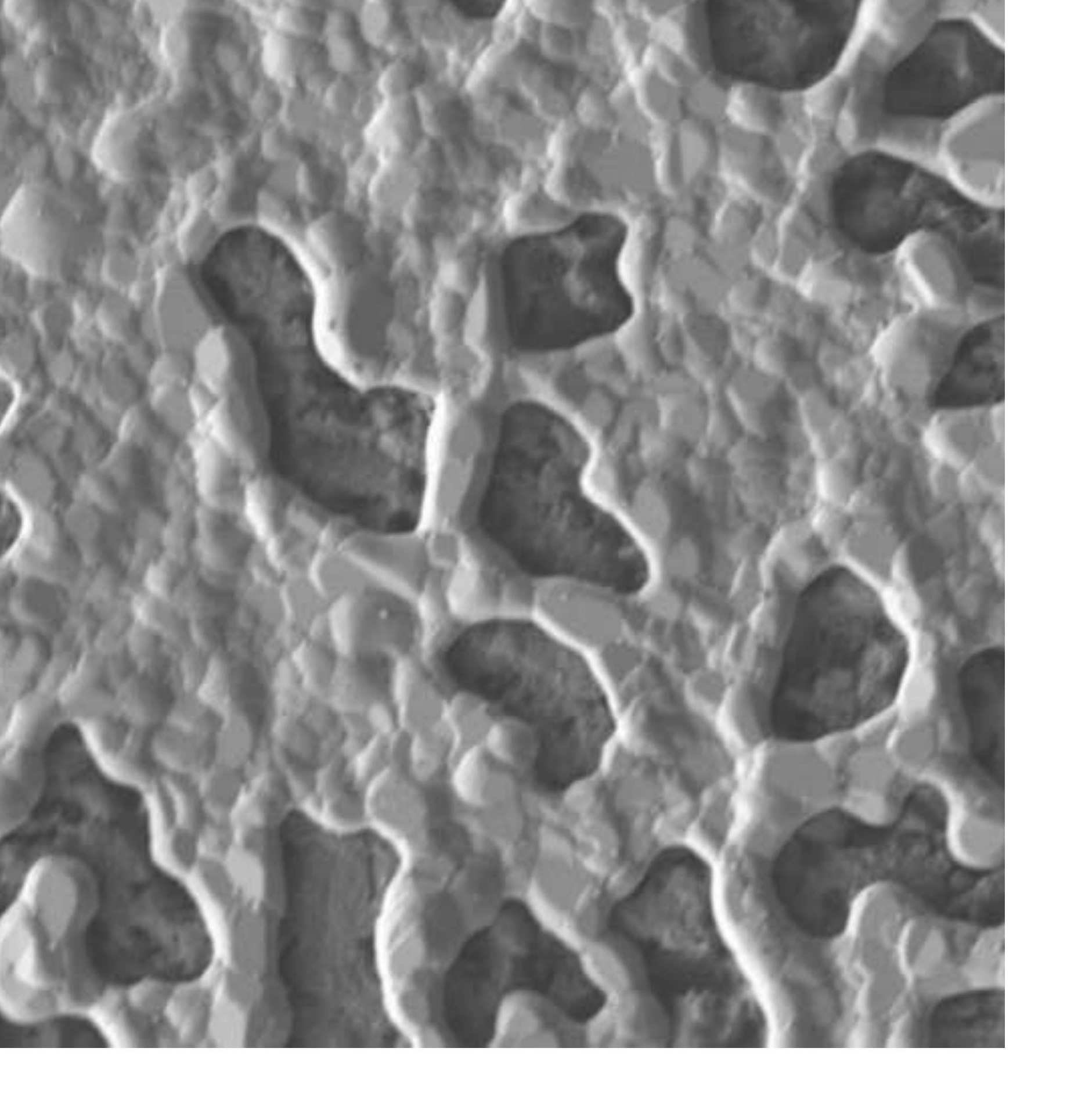

. 
Figure_4_b
Click here to download high resolution image

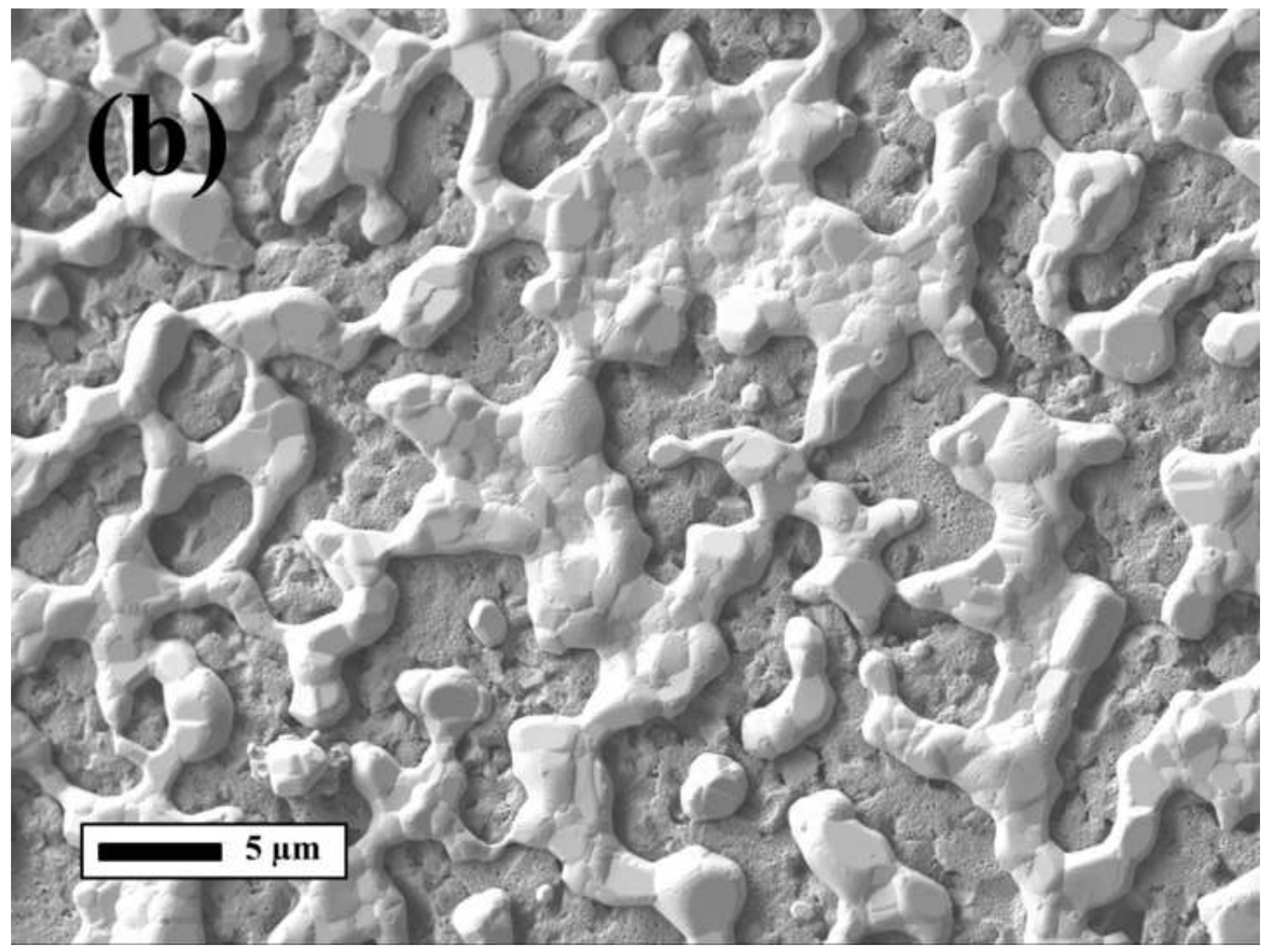




\section{densely packed Zr grains densely packed Zr grains (n)}

$\begin{aligned} & \text { Figure } 5 \text { a a } \\ & \text { click here to download high resolution image }\end{aligned}$
$\mathrm{Zr}$ adhesion layer consist of

Pt Grain

$200 \mathrm{~nm}$

Pi crin
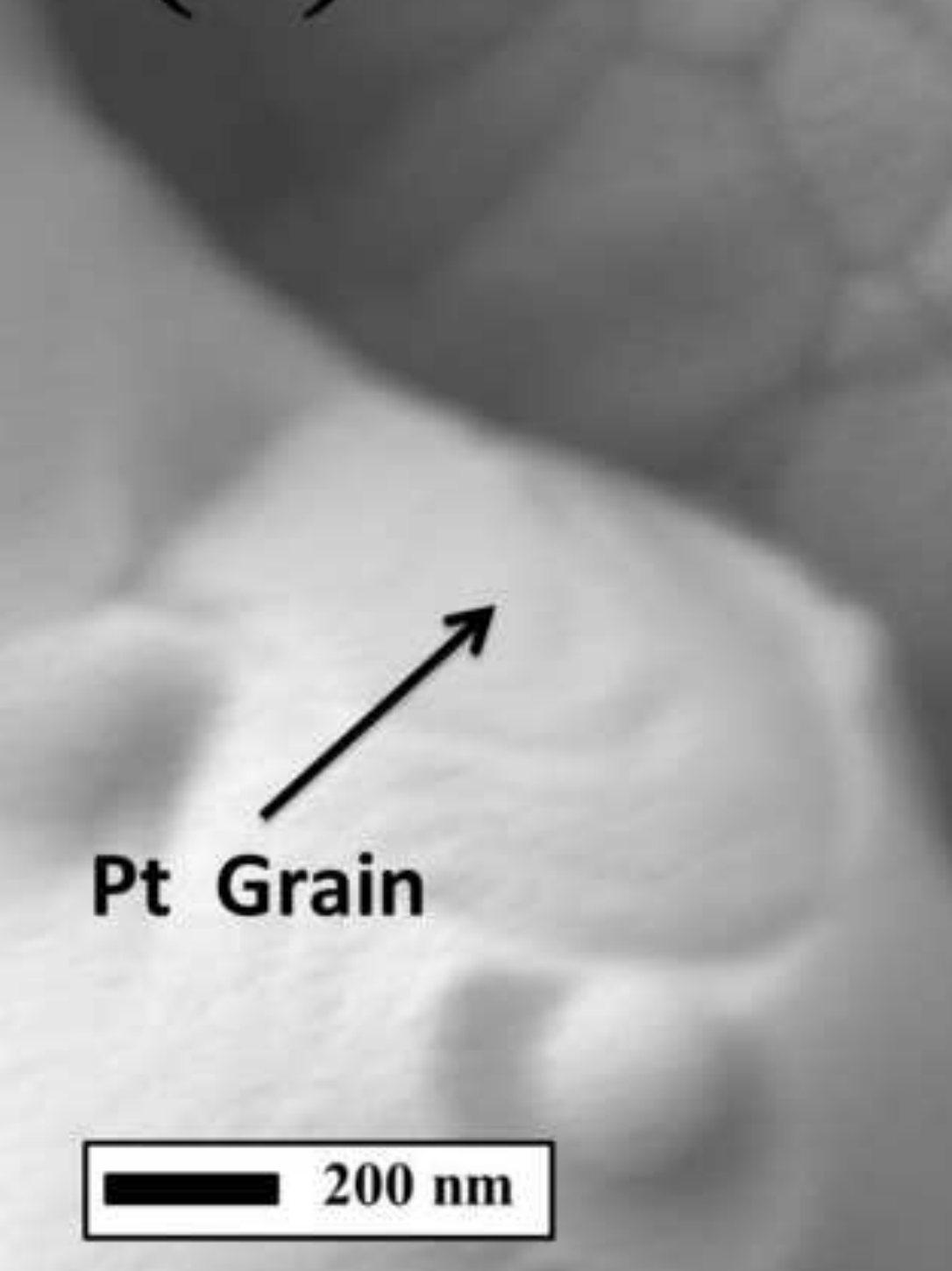

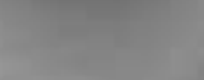

$x^{2}$

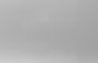

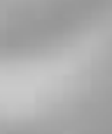
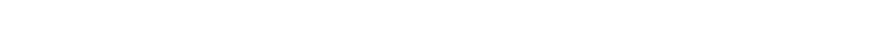

(1)

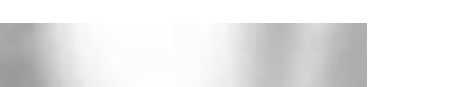

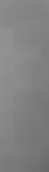

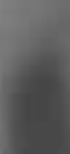
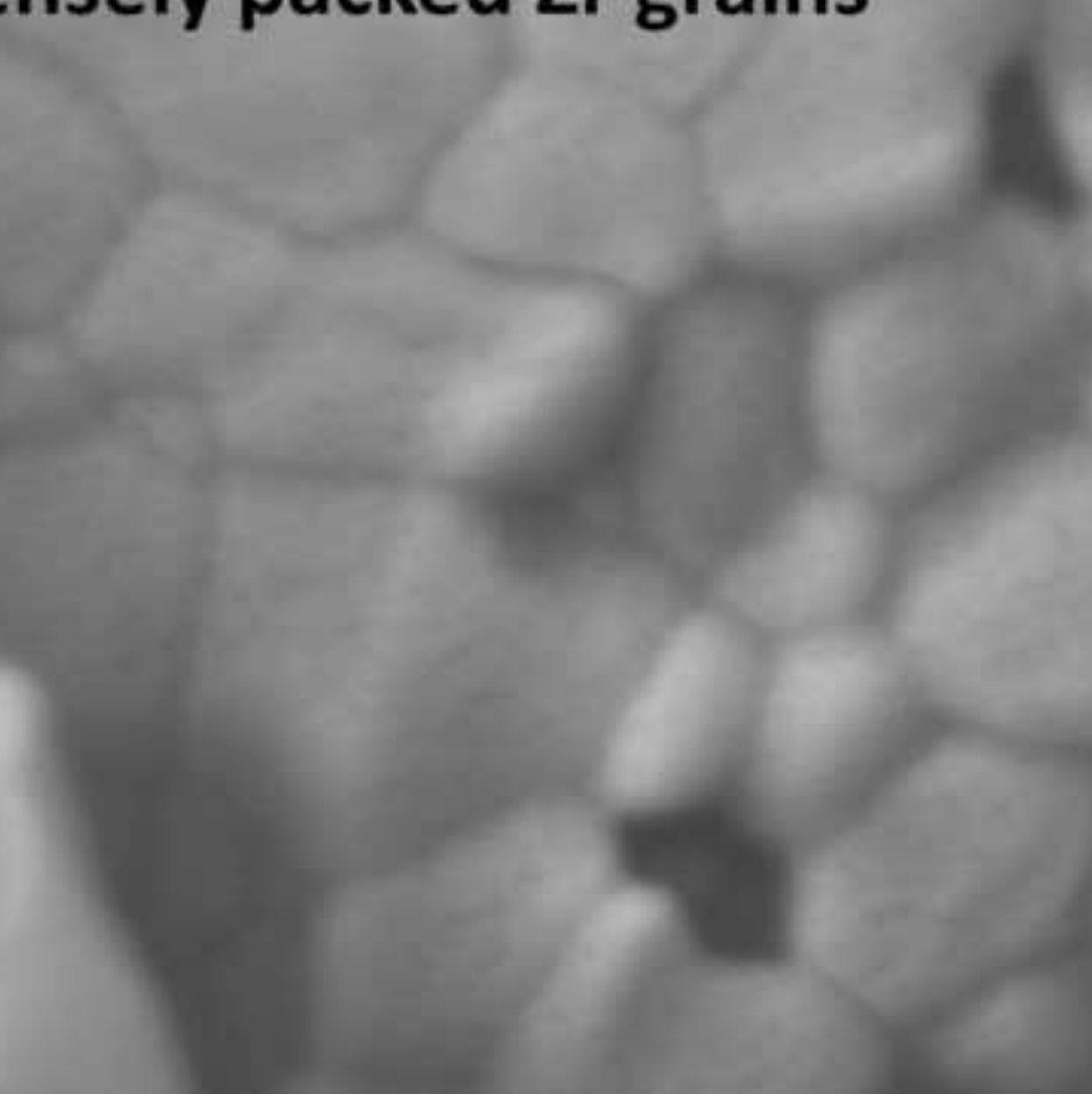


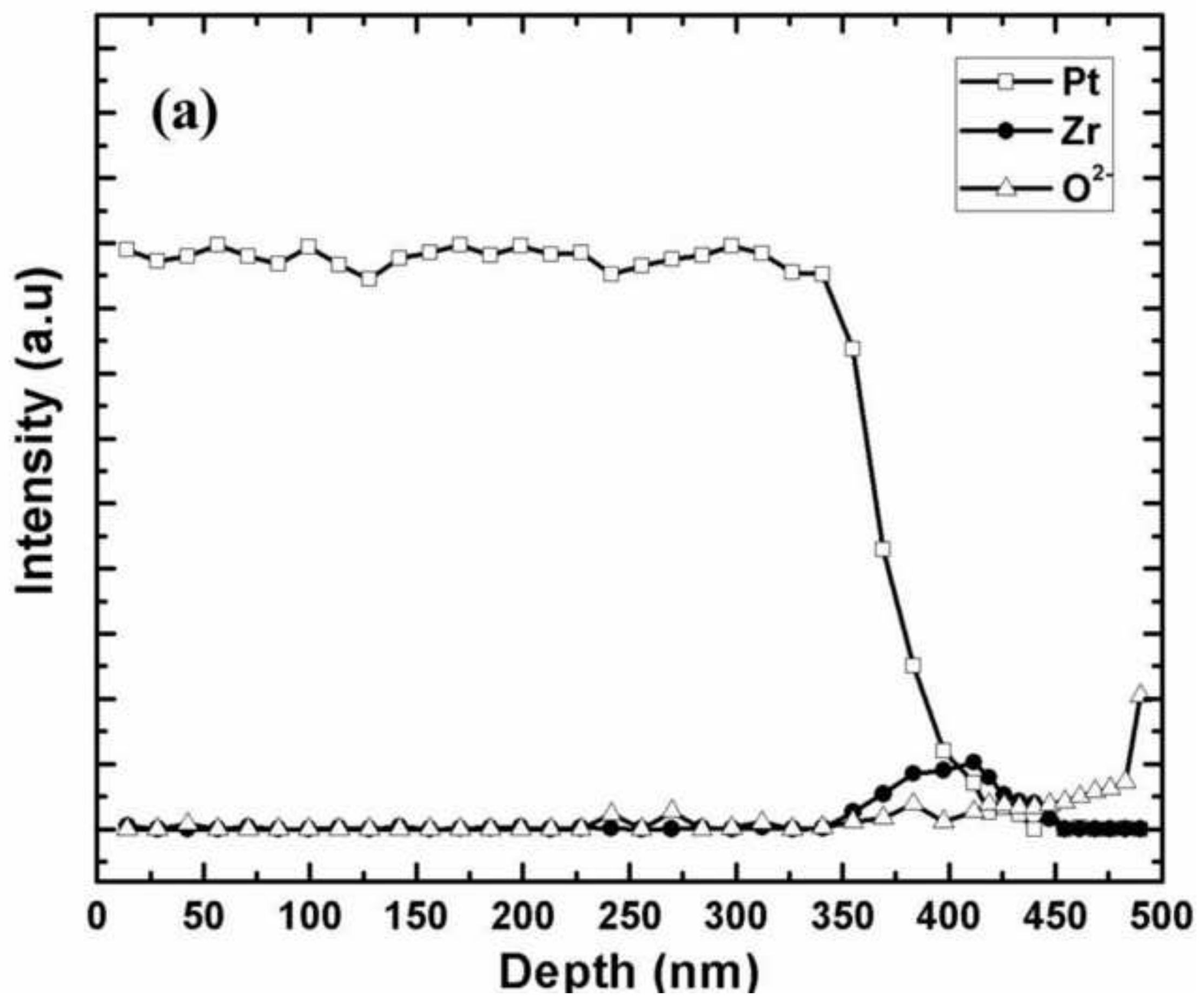




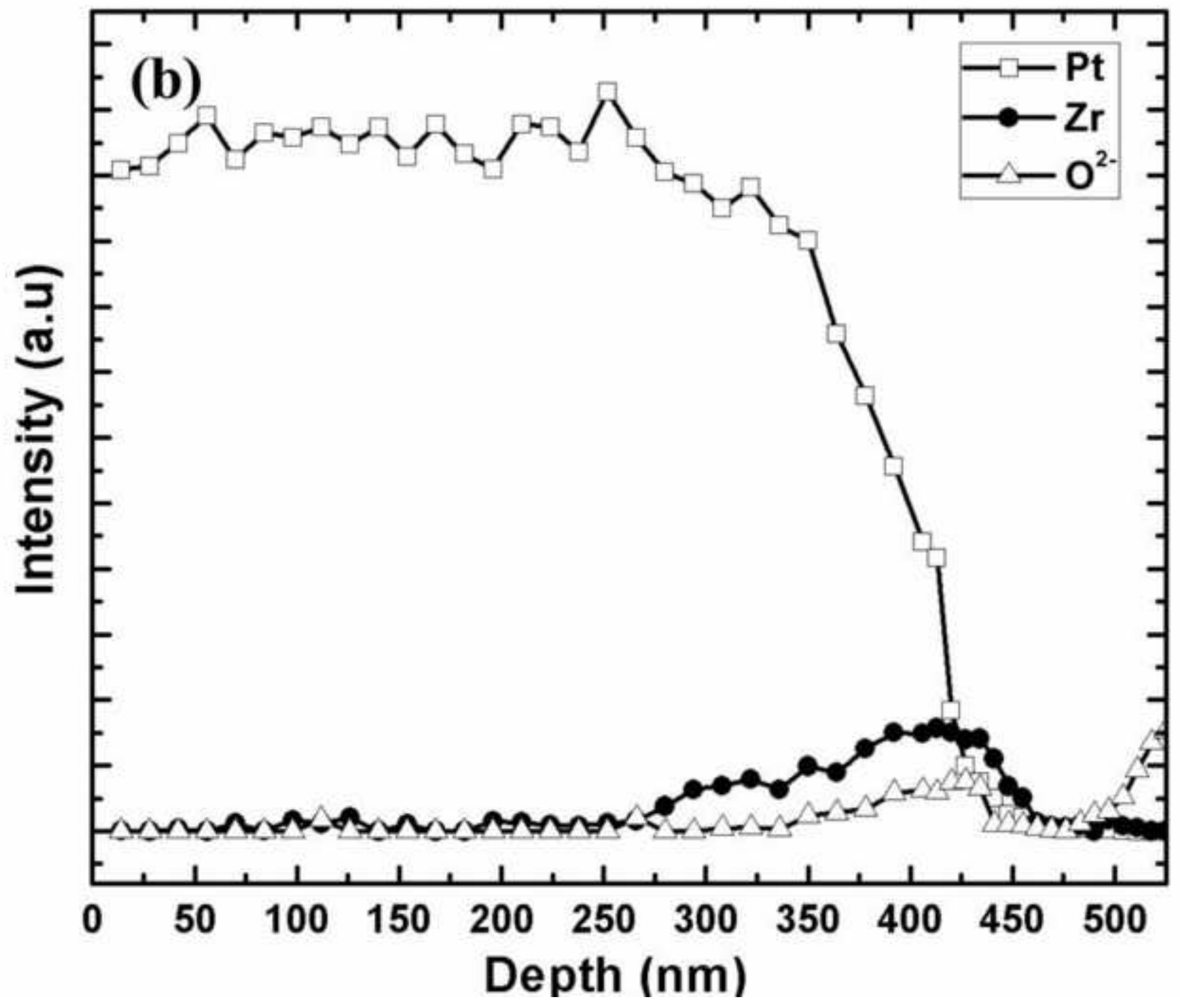




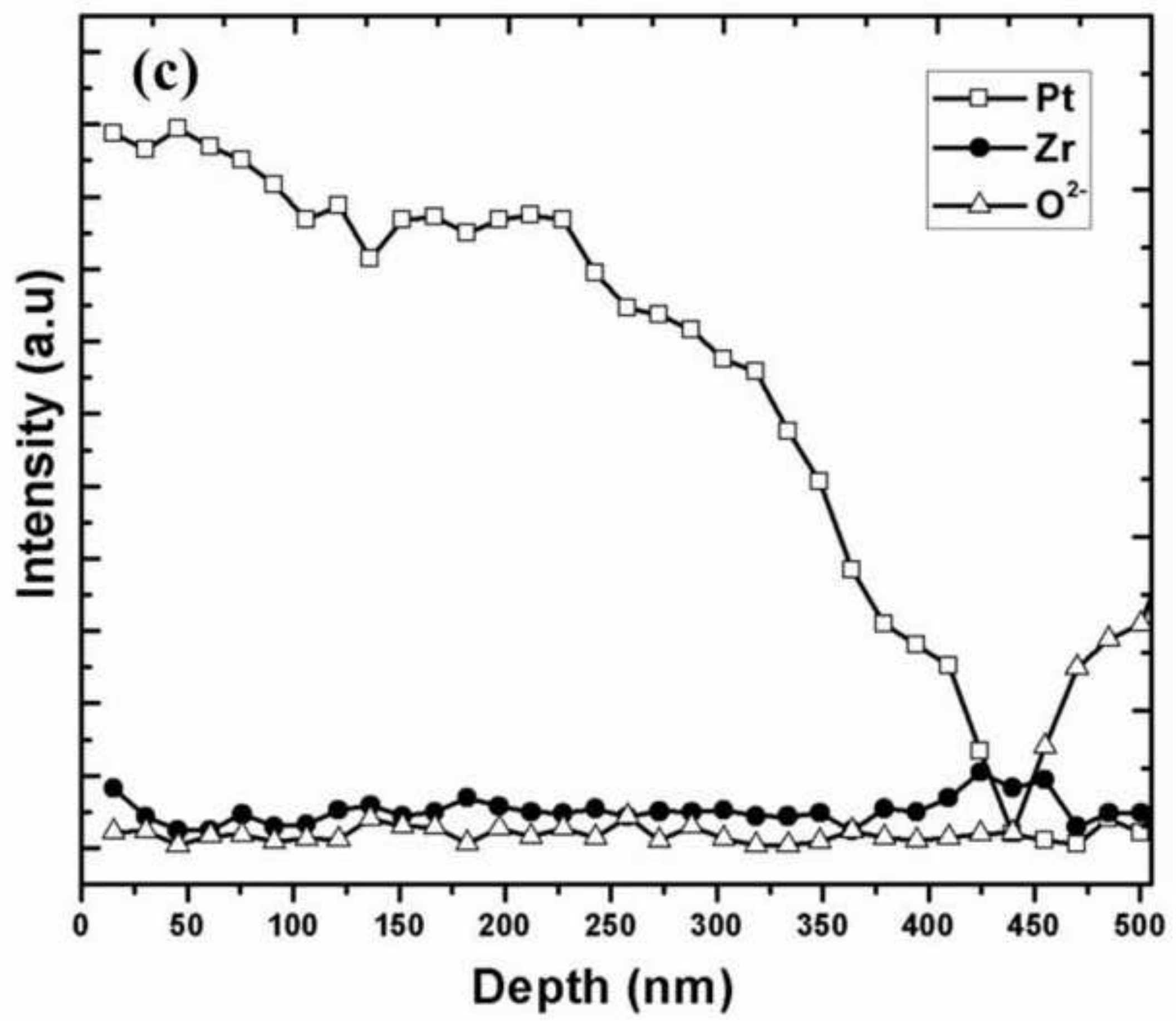




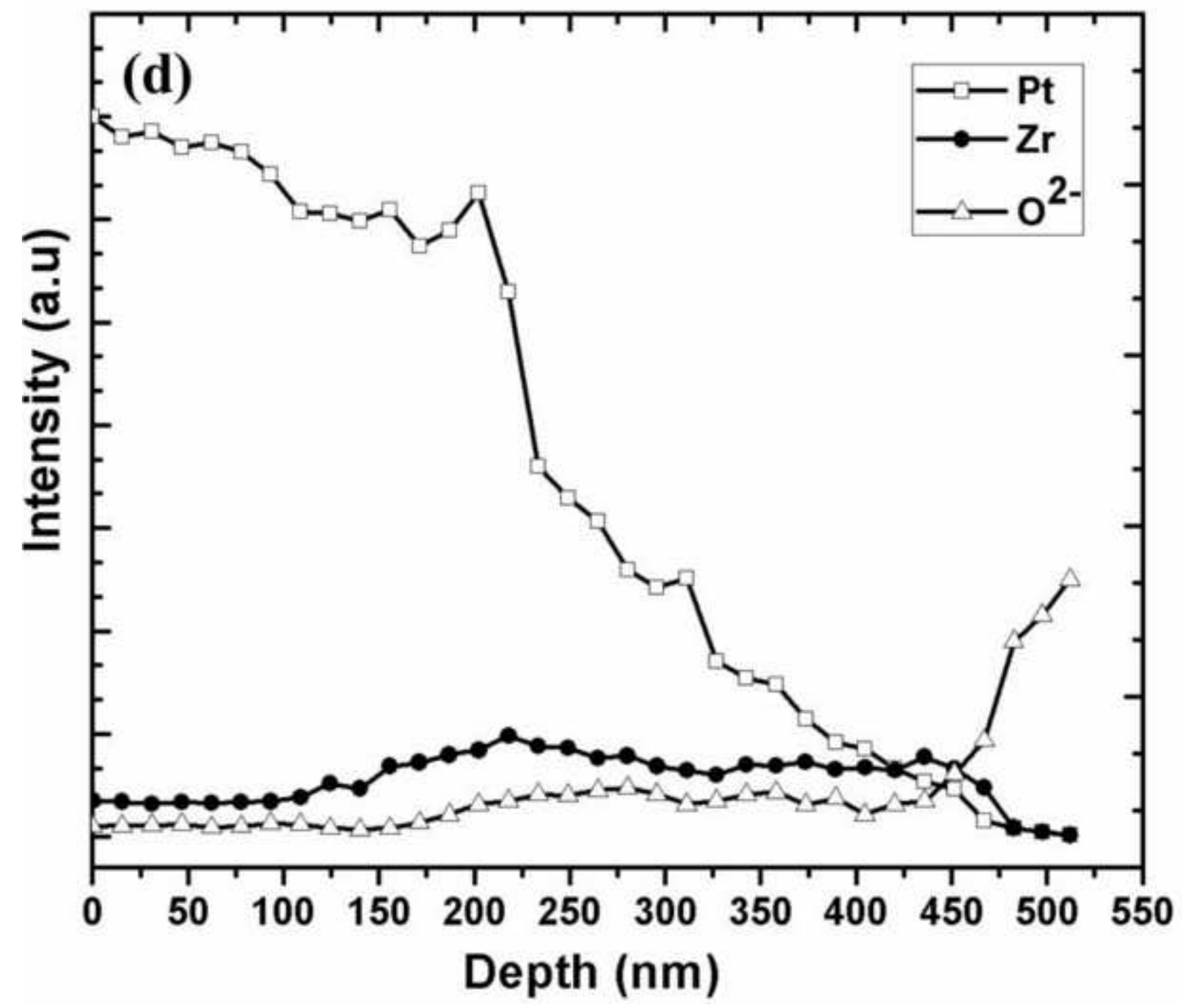


$\begin{array}{lllllllllll}0 & 10 & 20 & 30 & 40 & 50 & 60 & 70 & 80 & 90 & 100\end{array}$

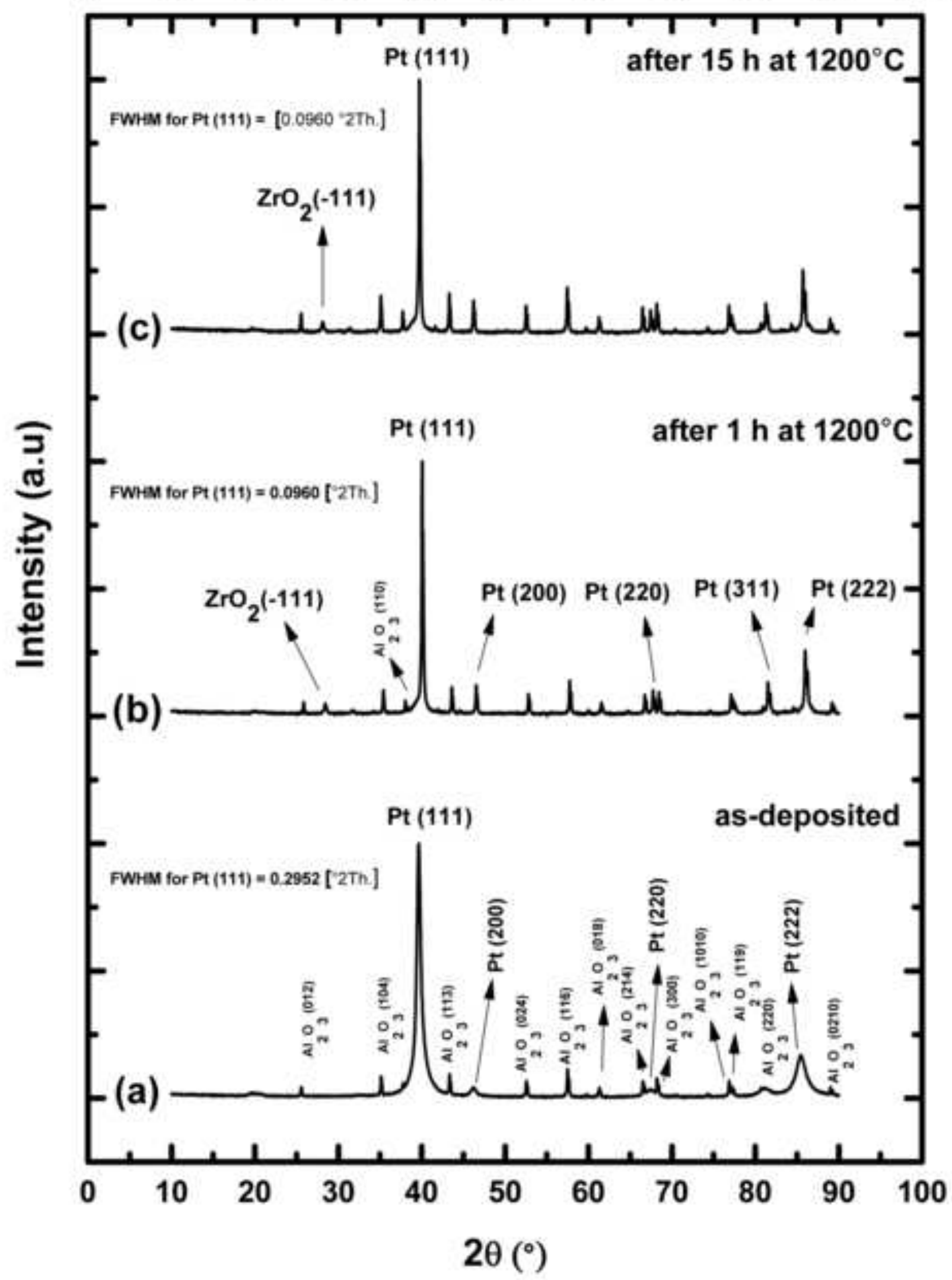


Figure_9_a_and_b

Click here to download high resolution image

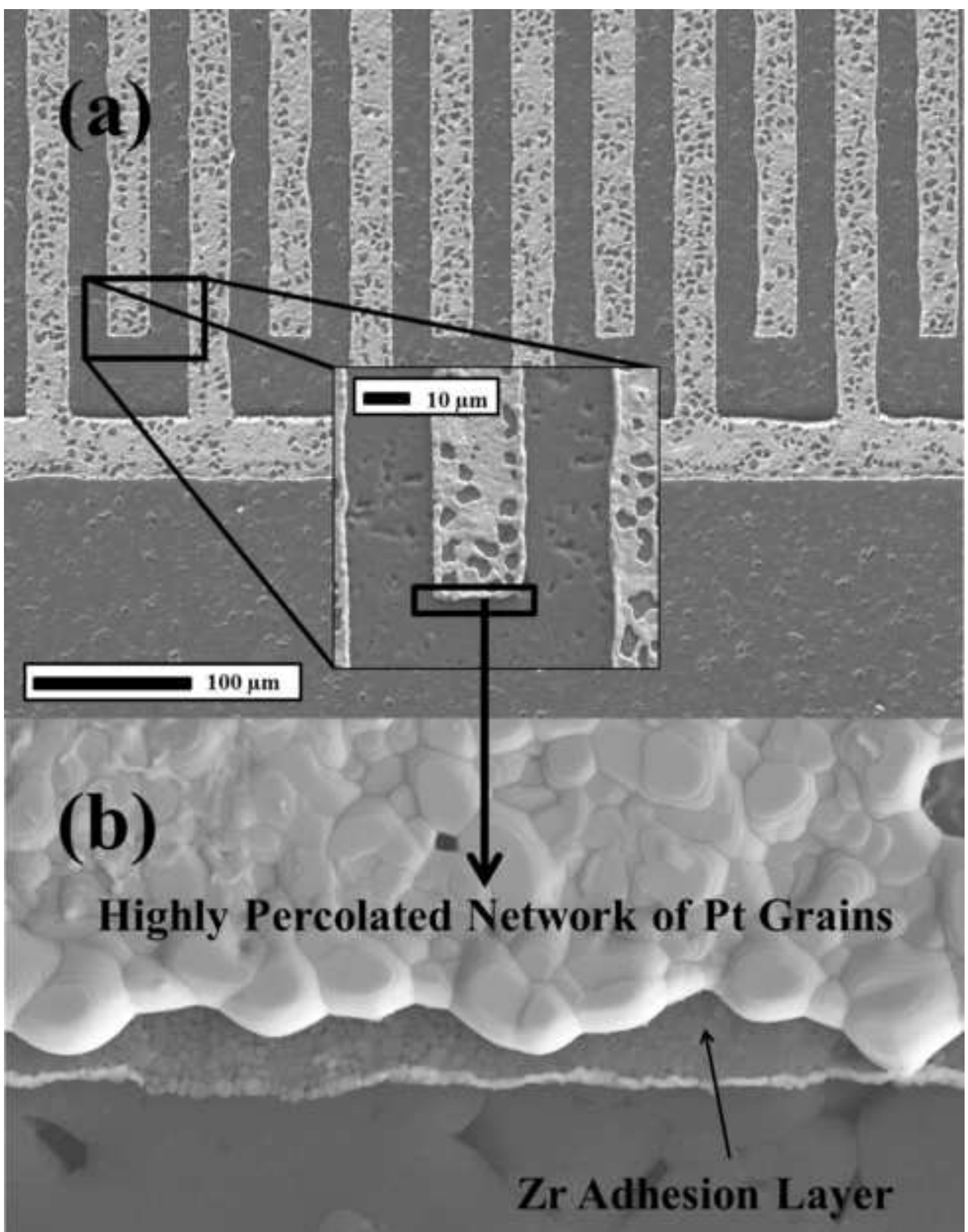

- $1 \mu \mathrm{m}$

$\mathrm{Al}_{2} \mathrm{O}_{3}$ Substrate 
Click here to download high resolution image

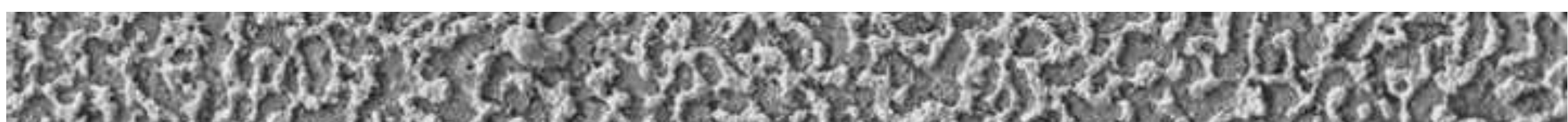

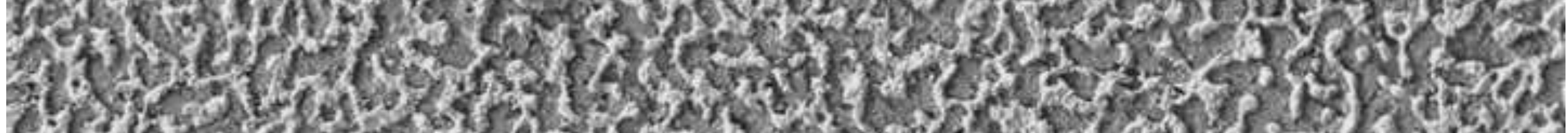

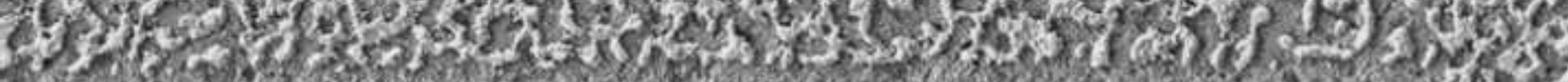

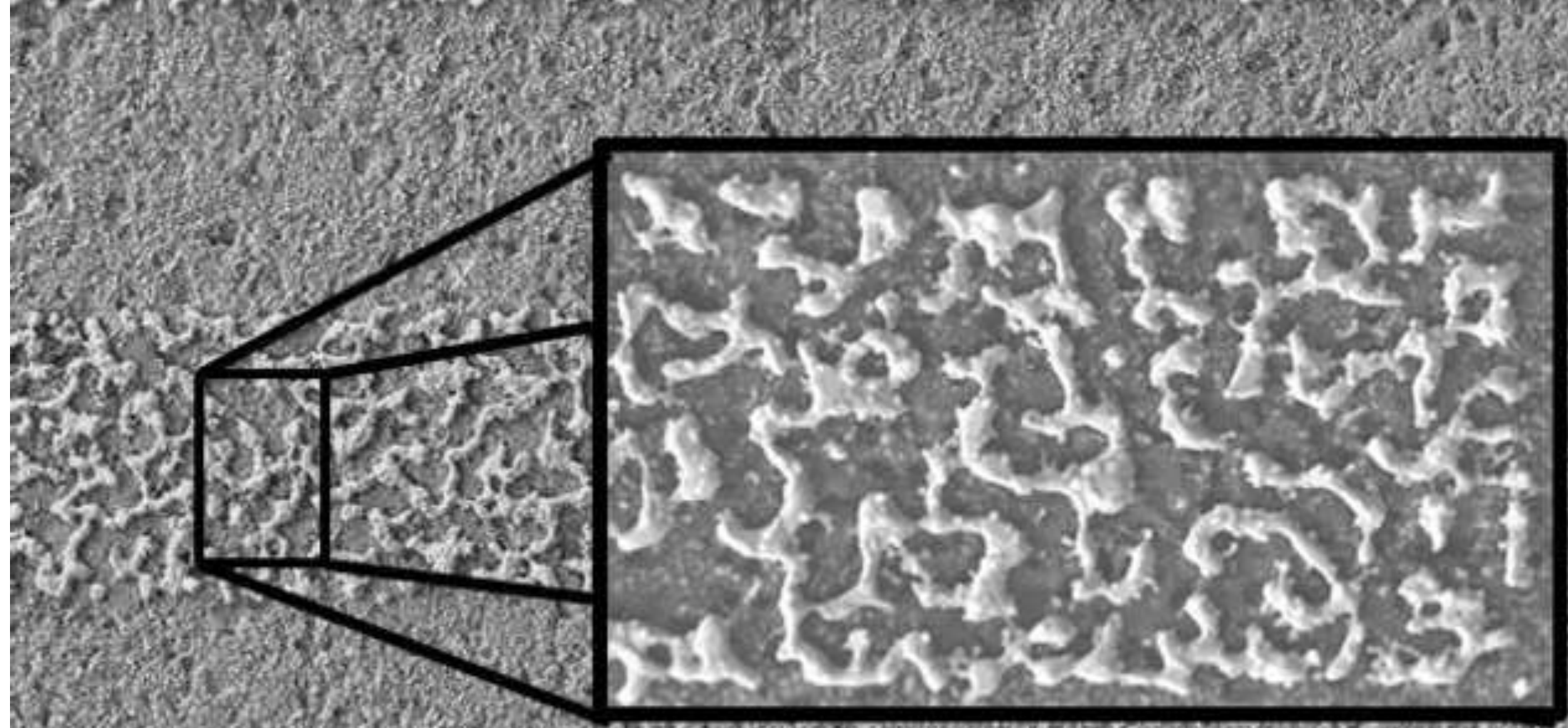

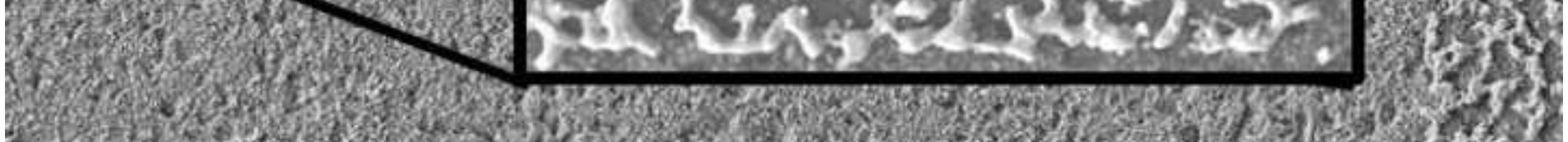

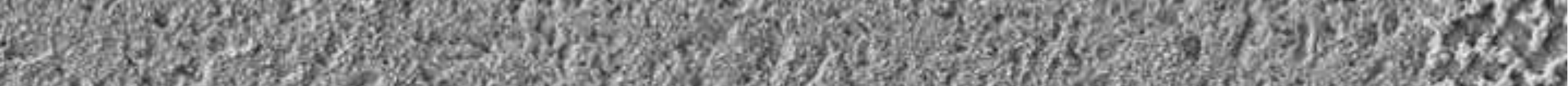

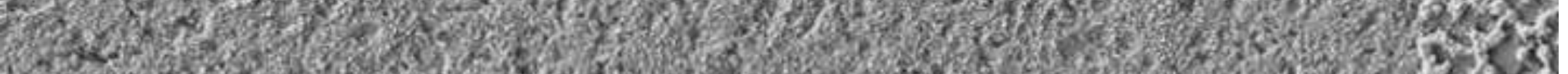
$-50 \mathrm{~m}$

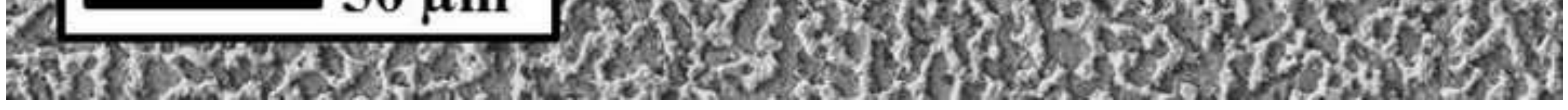


Engin Çiftyürek received the B.S. degree in physics engineering (2006) and M.S. degree in materials science and engineering (2009) from Istanbul Technical University (ITU). He earned his Ph.D. degree in mechanical engineering from West Virginia University (WVU) in 2014.

Colin D. McMillen earned his B.S. in Chemistry from Clemson University in 2002. He received his Ph.D. in Chemistry also from Clemson University in 2007, studying the hydrothermal crystal growth of various oxides and fluorides. He presently serves as the Director of the Molecular Structure Center in Clemson's Department of Chemistry, where he serves as a crystallographer and continues to examine unique approaches to crystal growth.

Katarzyna Sabolsky received the B.S. degree in ceramic engineering from Alfred University, Alfred, NY, in 1997, and the M.S. degree in material science and engineering from University of Florida, Gainesville, FL in 1999. She is currently an Associate Engineering Scientist at West Virginia University within Mechanical and Aerospace Engineering Department. Her research interests include high-temperature sensors, solid-state lithium ion batteries and solid oxide fuel cells.

Edward M. Sabolsky received his B.S. in ceramic science and engineering with a minor in metallurgical engineering from The Ohio State University in 1996. He completed his Ph.D. in materials Science and engineering at Pennsylvania State University in 2001. He joined NexTech Materials, Ltd. (NexTech) in 2001, where he continued his work in ceramic powder synthesis, forming, and thermal processing of piezoelectric/dielectric, sensor, catalyst, and solid-oxide fuel cell (SOFC) materials. In 2006, He assumed the position of Fuel Cell Group Leader at NexTech, where he managed the SOFC research group. He joined the Fine Ceramics and Igniter R\&D Group within the Saint-Gobain High-Performance R\&D Center in 2007 as a Senior Research Scientist. He finally moved to West Virginia University in 2008 as an Assistant Professor where he continues his work in advanced ceramic processing and materials development for energyrelated applications. 